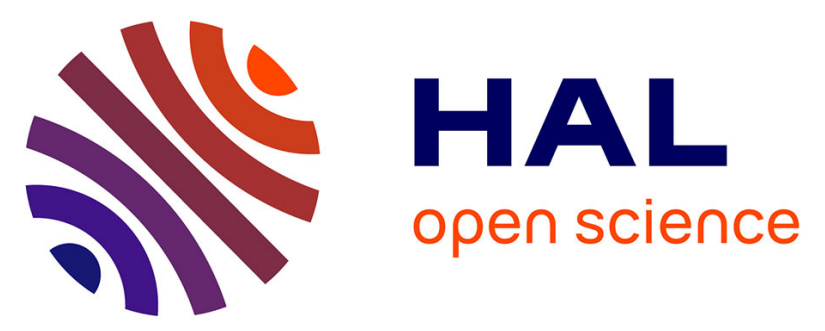

\title{
Experimental Assessment of Woody Biomass Gasification in a Hybridized Solar Powered Reactor featuring Direct and Indirect Heating Modes
} Axel Curcio, Sylvain Rodat, Valéry Vuillerme, Stéphane Abanades

\section{To cite this version:}

Axel Curcio, Sylvain Rodat, Valéry Vuillerme, Stéphane Abanades. Experimental Assessment of Woody Biomass Gasification in a Hybridized Solar Powered Reactor featuring Direct and Indirect Heating Modes. International Journal of Hydrogen Energy, 2021, 10.1016/j.ijhydene.2021.09.008 . hal-03363697

\author{
HAL Id: hal-03363697 \\ https://hal.science/hal-03363697
}

Submitted on 4 Oct 2021

HAL is a multi-disciplinary open access archive for the deposit and dissemination of scientific research documents, whether they are published or not. The documents may come from teaching and research institutions in France or abroad, or from public or private research centers.
L'archive ouverte pluridisciplinaire HAL, est destinée au dépôt et à la diffusion de documents scientifiques de niveau recherche, publiés ou non, émanant des établissements d'enseignement et de recherche français ou étrangers, des laboratoires publics ou privés. 


\title{
Experimental Assessment of Woody Biomass Gasification in a Hybridized Solar Powered Reactor featuring Direct and Indirect Heating Modes
}

\author{
Axel Curcio ${ }^{1}$, Sylvain Rodat ${ }^{1}$, Valéry Vuillerme ${ }^{2}$, Stéphane Abanades ${ }^{1 \text { * }}$ \\ ${ }^{1}$ Processes, Materials and Solar Energy Laboratory, PROMES - CNRS, \\ 7 rue du Four Solaire, 66120 Font-Romeu Odeillo, France \\ ${ }^{2}$ Univ. Grenoble Alpes INES - CEA, \\ 50 avenue Lac Léman, 73375 Le Bourget-du-Lac, France \\ * Corresponding author. Email: stephane.abanades@promes.cnrs.fr. Phone: + 33 (0)4 68307730.
}

\begin{abstract}
Solar thermochemical gasification is an opportunity for the production of sustainable fuels from carbonaceous resources including biomass. Substituting conventional gasification processes by solardriven technologies may enable cleaner production of $\mathrm{H}_{2}$-rich syngas while saving feedstock resources and alleviating $\mathrm{CO}_{2}$ emissions. This work addresses hybrid solar-autothermal gasification of mm-sized beech wood particles in a lab-scale $1.5 \mathrm{~kW}_{\text {th }}$ spouted-bed reactor. Hybridization under reduced solar power input was performed by injecting oxygen and additional biomass inside the gasifier for complementary heat supply. Increasing $\mathrm{O}_{2}: \mathrm{C}$ molar ratios (in the range 0.14-0.58) allowed to heat the reactor cavity and walls progressively, while gradually impairing the reactor performance with an increase of the syngas $\mathrm{CO}_{2}$ content and a decrease of the reactor cold gas efficiency (CGE). Gasification with mixed $\mathrm{H}_{2} \mathrm{O}$ and $\mathrm{O}_{2}$ was then assessed at thermodynamic equilibrium and global trends were validated experimentally, showing that control of $\mathrm{H}_{2}: \mathrm{CO}$ ratio was compatible with in-situ combustion. The impact of reaction temperature $\left(1200-1300^{\circ} \mathrm{C}\right)$ and heating mode (direct or indirect) was experimentally studied during both allothermal and hybrid gasification. Higher $\mathrm{H}_{2}$ and $\mathrm{CO}$ yields were achieved at high temperatures $\left(1300^{\circ} \mathrm{C}\right)$ under direct reactor heating. Hybridization was able to counterbalance a $40 \%$ drop of the nominal solar power input, and the measured CGE reached 0.82, versus values higher than 1 during allothermal gasification.
\end{abstract}

\section{KEYWORDS}

Solar Fuels, Biomass Steam-Gasification, Spouted-Bed Reactor, Hybridization, Concentrated solar energy, Continuous Operation.

\section{INTRODUCTION}

Solar gasification of biomass into a hydrogen-rich syngas has been developed for both power generation and chemical process integration. Since the first solar gasification experiments in 1980 [1], high storage potential of solar energy has been reported and solar gasification process economics has been assessed [2,3]. Different solar reactor designs were proposed [3-5] including packed bed 
gasifiers [6-9], fluidized beds [6,10], vortex-flow reactors [11] and molten-salt and molten-slag based designs [12,13]. More recently, dual fluidized-bed reactors [14-17], vortex-flow [18,19], spouted-bed [20-22], and molten-salt based gasifiers $[23,24]$ have been considered. However, in order to overcome the variability of solar resource, reactor hybridization has been recently investigated to ensure both allothermal (solar only) and hybrid allothermal-autothermal (combustion-aided) gasification. Boujjat et al. [25] experimentally studied beech wood gasification by steam at temperatures in the range 1200$1300^{\circ} \mathrm{C}$ (Equation 1). Injection of oxygen and additional biomass aimed to initiate combustion (Equation 2), in order to compensate for solar power input daily variations. Partial oxidation might also take place to a certain extent (Equation 3), leading to a less endothermic production of $\mathrm{H}_{2}$ and $\mathrm{CO}$.

Steam gasification of dry beech wood:

$$
\mathrm{CH}_{1.66} \mathrm{O}_{0.69}+0.31 \mathrm{H}_{2} \mathrm{O}_{(\mathrm{v})} \rightarrow \mathrm{CO}+1.14 \mathrm{H}_{2} \quad \Delta \mathrm{H}^{\circ}{ }_{1}=143.4 \mathrm{~kJ} / \mathrm{mol}
$$

Oxy-combustion of dry beech wood:

$$
\mathrm{CH}_{1.66} \mathrm{O}_{0.69}+1.07 \mathrm{O}_{2} \rightarrow \mathrm{CO}_{2}+0.83 \mathrm{H}_{2} \mathrm{O} \quad \Delta \mathrm{H}^{\circ}{ }_{2}=-451.9 \mathrm{~kJ} / \mathrm{mol}
$$

Partial oxidation of dry beech wood:

$$
\mathrm{CH}_{1.66} \mathrm{O}_{0.69}+0.155 \mathrm{O}_{2} \rightarrow \mathrm{CO}+0.83 \mathrm{H}_{2} \quad \Delta \mathrm{H}^{\circ}{ }_{3}=68.3 \mathrm{~kJ} / \mathrm{mol}
$$

The actual gasification mechanism comprises multiple side reactions. The two major ones are the pyrolysis of the carbonaceous feedstock (thermal devolatilization of biomass into char, steam, light gases and tars) and the gasification of char (highly endothermic oxidation into $\mathrm{H}_{2}$ and $\mathrm{CO}$ ). The distribution of pyrolysis products varies a lot from one experimental setup to another, depending on the heating rate, residence time and biomass characteristics, and so does the reaction enthalpy. The general reaction used by Boujjat et al. [26] in their modelling work is given in Equation 4, where phenol accounts for intermediate tars and hydrocarbons. Char gasification (Equation 5) has been well mastered since the 1930s [27], and it is known for working in pair with the water-gas shift reaction [28] that regulates the balance between $\mathrm{H}_{2}$ and $\mathrm{CO}$ quantities (Equation 6). Hydrogen and carbon monoxide are also produced via steam reforming reaction (Equation 7). Numerous other reaction mechanisms have been detailed to account for the formation of gas hydrocarbons and tars [29]. Modelling techniques such as distributed activation energy model and multi-box approach have been confronted [30,31], but no universal model is yet used for all gasifier designs, as the reaction is strongly dependent on operating conditions (feedstock characteristics, reaction temperature, and pressure).

Pyrolysis of biomass:

$$
\text { Biomass } \rightarrow \gamma_{1} \mathrm{CO}+\gamma_{2} \mathrm{H}_{2}+\gamma_{3} \mathrm{CO}_{2}+\gamma_{4} \mathrm{CH}_{4}+\gamma_{5} \mathrm{H}_{2} \mathrm{O}+\gamma_{6} \mathrm{C}_{6} \mathrm{H}_{5} \mathrm{OH}+\gamma_{7} \mathrm{C}_{(\mathrm{s})}
$$

Gasification of char:

$$
\mathrm{C}_{(\mathrm{s})}+\mathrm{H}_{2} \mathrm{O} \rightarrow \mathrm{CO}+\mathrm{H}_{2}
$$

$$
\Delta \mathrm{H}_{5}^{\circ}=131 \mathrm{~kJ} / \mathrm{mol}
$$

Water-gas shift:

$$
\mathrm{H}_{2} \mathrm{O}+\mathrm{CO} \leftrightarrow \mathrm{H}_{2}+\mathrm{CO}_{2} \quad \Delta \mathrm{H}_{6}^{\circ}=-42 \mathrm{~kJ} / \mathrm{mol}
$$

Steam methane reforming:

$$
\mathrm{CH}_{4}+\mathrm{H}_{2} \mathrm{O} \rightarrow \mathrm{CO}+3 \mathrm{H}_{2} \quad \Delta \mathrm{H}^{\circ}{ }_{7}=206 \mathrm{~kJ} / \mathrm{mol}
$$

In the domain of spouted-bed technologies, recent research works tackled the impact of temperature (in the range $800-900^{\circ} \mathrm{C}$ ) on tars formation [32], or the impact of gases flow rates, biomass properties and temperature (in the range $1100-1300^{\circ} \mathrm{C}$ ) on gasifier performance [33,34]. Addition of a bed of inert particles (alumina, $\mathrm{SiC}$, olivine, sand) has also been investigated to improve the thermal inertia of 
solar reactors [35]. Besides, the effect of simultaneous steam and oxygen injection has been mapped during fully autothermal [36] and hybrid [37] operation. In the latter case, optimal reactant flow rates were identified as a function of the solar flux by thermodynamic calculations. Regarding advanced control strategies, Petrasch et al. [38] introduced a simplified feedback method that was applied to existing solar allothermal gasifier designs. The $\mathrm{CO}_{2}$ concentration in the syngas was controlled by modifying the steam input flow rate, which resulted in improved reactor efficiency over time. Saade et al [39] applied a model predictive control algorithm to manage the output $\mathrm{CO}: \mathrm{CO}_{2}$ ratio using a highly non-linear model of the reactor. Then, in the field of combustion-aided gasification, Muroyama et al. [40] used a linear dynamic model to control the temperature of a fluidized-bed reactor through simultaneous injection of $\mathrm{O}_{2}$ and additional feedstock. This resulted in a reduction of the theoretical $\mathrm{CO}_{2}$ emission in the range $17.8-22.8 \%$ between fully autothermal mode and hybrid operation depending on the season. Boujjat et al. [41] proposed an extrapolated OD model based on thermodynamic equilibrium to validate the feasibility of dynamic control over the year. They assessed the impact of hybridization on syngas quality: in particular, the $\mathrm{H}_{2}: \mathrm{CO}$ mole ratio might drop from 1.2 to 0.8 between solar-only and hybrid regimes. Experiments carried out by Muroyama et al. [42] demonstrated that this effect could be countered by injecting additional steam in hybrid mode. In general, tuning of the syngas quality might be possible by adjusting both steam and oxygen injection, which was detailed by $\mathrm{Li}$ et al. [37] on the basis of thermodynamic analysis. Hathaway et al. [43] recently adapted their molten-salt-based gasifier to perform hybrid operation and to control the $\mathrm{H}_{2}$ :CO ratio, with an experimental validation that steam addition could permit to control the syngas quality (via steam shifting). This objective was justified by the need to integrate solar hybrid gasifiers into continuous industrial demonstrators and to provide a constant syngas output composition for stable downstream processing. To date, limited experimental work was carried out in this field and data are required to bridge the gap between theoretical results with practical observations. In addition, insights into the process dynamic behavior are of special interest.

This study presents experimental results obtained in a hybridized spouted-bed solar gasifier. The goal is to validate the feasibility of continuous wood gasification under decreasing solar power input, thanks to hybrid solar-autothermal operation. A study of the impact of oxygen to carbon ratio $\left(\mathrm{O}_{2}: \mathrm{C}\right)$ and of the combination of oxygen with steam is provided, to identify precise trends regarding reactor performance and to compare them to calculations made at thermodynamic equilibrium (TE). The role of temperature is assessed in the range $1200-1300^{\circ} \mathrm{C}$ during both allothermal and hybrid gasification, and the performances achieved under direct and indirect heating modes are compared during continuous hybrid operation. Finally, the dynamics of hybridization during a decrease of the solar power input are discussed.

\section{MATERIALS AND METHODS}

The lab-scale gasifier, detailed in Figure 1, was operated under real concentrated solar power. Incident sunlight was reflected upwards by a heliostat and concentrated by a parabolic mirror of $2 \mathrm{~m}$ diameter placed above the reactor. After crossing the glass window positioned at the top of the reactor, the concentrated solar flux entered the cavity via a small aperture (20 mm diameter) on the alumina cap. This front aperture plate was covered with a layer of zirconia and graphite felts to reduce radiation losses. The power absorbed by the reactor cavity under a DNI (Direct Normal Irradiation) of $1 \mathrm{~kW} / \mathrm{m}^{2}$ equaled $\sim 1.5 \mathrm{~kW}_{\text {th }}$, according to calorimetry measurements. In direct heating mode, concentrated sunlight directly entered the cavity. In indirect heating mode, an additional $2 \mathrm{~mm}$-thick SiC-coated graphite plate was set below the alumina cap to absorb solar radiation and re-emit heat as infrared radiation towards the bottom cavity. The reactor cavity was insulated by a surrounding $3 \mathrm{~cm}$ thick layer of porous ceramic fiber. A water circuit allowed cooling of the external stainless-steel reactor envelope.

Spouting of the particles was achieved in a $68 \mathrm{~mm}$ high and $60^{\circ}$ cone topped by a cylindrical piece (78 $\mathrm{mm}$ inner diameter), both made of high-temperature resistant metallic $\mathrm{FeCrAl}$ alloy. The cavity 
volume (comprised under the position of the emitter plate) was $0.24 \mathrm{~L}$. Irregularly-shaped beech wood particles (Figure 1, characteristics given in Table 1) were fed by a screw driver in the upper part of the cavity and dropped by gravity inside the cavity. Oxidizing agents mixed with a flow of argon $(0.2$ $\mathrm{NL} / \mathrm{min}$ ) were provided down the cavity with sufficient velocity to vigorously stir the bulk reacting solid. Argon was also injected through the hopper and screw driver $(0.5 \mathrm{NL} / \mathrm{min})$ with the biomass to limit counterflow heat and mass transfer in the injection tube, and in the window region $(2 \mathrm{NL} / \mathrm{min})$ to keep it clean from pyrolytic gases. A $1.5 \mathrm{~cm}$-height bed of $\mathrm{Al}_{2} \mathrm{O}_{3}$ inert particles $(2-3 \mathrm{~mm}$ size $)$ was placed at the cone base to protect the injection tube from thin char and ash residues.
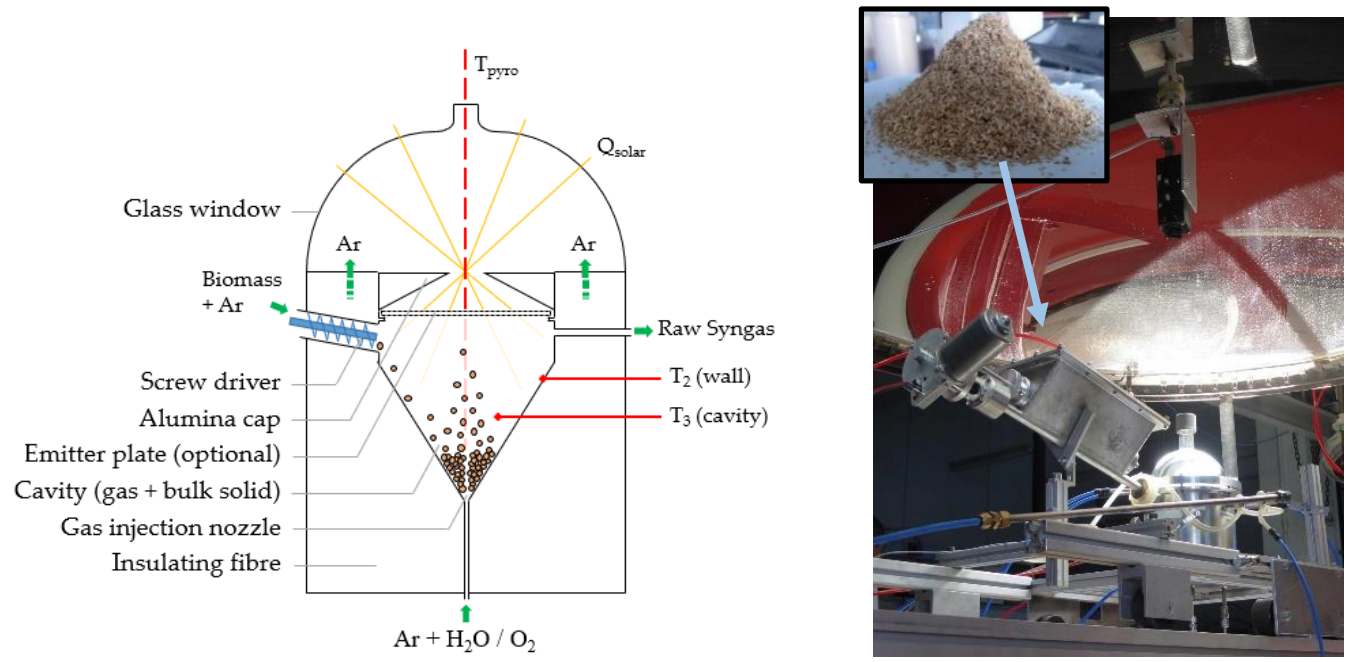

Figure 1. Scheme and photograph of the solar gasification reactor (inset: photograph of the beech wood particles).

Inlet gas flow rates were managed by mass flow controllers (BROOKS $5850 \mathrm{~S}$ ). Water injection was ensured by a liquid mass flow controller (HORIBA SILV-F30P). Wood particles were injected by a screw driver calibrated before the experimental campaign. Outlet syngas concentrations $\left(\mathrm{H}_{2}, \mathrm{CO}, \mathrm{CO}_{2}\right.$, $\mathrm{CH}_{4}$ ) were measured by an online analyzer (GEIT GAS 3100 SYNGAS, one measurement every 3 seconds) and by a gas chromatograph (GC, Varian CP49000, one measurement every 2 or 3 minutes) after the outlet gas flowed through a bubbler and two micro-filters to remove remaining moisture and entrained char particles. $\mathrm{GC}$ was mainly used to measure yields of light gas hydrocarbons $\left(\mathrm{C}_{2} \mathrm{H}_{\mathrm{m}}\right.$, as the sum of $\mathrm{C}_{2} \mathrm{H}_{2}, \mathrm{C}_{2} \mathrm{H}_{4}$ and $\mathrm{C}_{2} \mathrm{H}_{6}$ species, precision of $\pm 1 \%$ ).

Located at the center of the parabolic mirror, a solar-blind pyrometer $(4.8-5.2 \mu \mathrm{m}$, pointing through a $\mathrm{CaF}_{2}$ window) estimated the temperature $\left(\mathrm{T}_{\text {pyro }}\right)$ of the emitter plate (in indirect heating mode) or the temperature of the bulk solid inside the spouted-bed (in direct heating mode). The temperature of the conical cavity external wall, which was found to be quite homogeneous [44], was measured by a Btype thermocouple $\left(\mathrm{T}_{2}\right)$. Another thermocouple, shielded with an alumina tube, was placed inside the cavity to estimate the temperature at its center $\left(\mathrm{T}_{3}\right)$. Pressures were also monitored, though they usually stayed slightly above atmospheric pressure $(0.85$ to 0.9 atm due to the location of the laboratory at an altitude of $1600 \mathrm{~m}$ ).

Table 1. Beech wood characteristics (dry basis).

\begin{tabular}{cccccccccc}
\hline $\begin{array}{c}\mathbf{C} \\
(\text { wt. \%) }\end{array}$ & $\begin{array}{c}\mathbf{H} \\
(\text { wt. \%) }\end{array}$ & $\begin{array}{c}\mathbf{O} \\
(\text { wt.\%) }\end{array}$ & $\begin{array}{c}\mathbf{N} \\
(\text { wt.\%) }\end{array}$ & $\begin{array}{c}\text { S } \\
(\text { wt.\%) }\end{array}$ & $\begin{array}{c}\text { Ash } \\
(\text { wt.\%) }\end{array}$ & $\begin{array}{c}\text { Cl } \\
(\text { wt.\%) }\end{array}$ & $\begin{array}{c}\text { Moisture } \\
\text { (wt.\%) }\end{array}$ & $\begin{array}{c}\text { LHV } \\
\text { (MJ/kg) }\end{array}$ & Diameter \\
\hline 48.3 & 6.7 & 44.4 & 0.1 & $<0.1 \%$ & 0.4 & $<0.1 \%$ & 8.9 & 16.8 & $<2 \mathrm{~mm}$ \\
\hline
\end{tabular}

Syngas compositions were systematically compared with compositions calculated at Thermodynamic Equilibrium (TE), by minimizing the system's Gibbs free energy under similar operating conditions (closed system approach). This was done using the CANTERA [45] open library in Python, which featured a calculation environment with a rich database of species thermodynamic properties. Char 
was modeled by solid graphite, and species taken from the GRI30 dataset were used to model the gas phase. The input biomass and oxidant were represented by an equivalent mixture of char, $\mathrm{H}_{2}$ and $\mathrm{O}_{2}$. TE was calculated under constant temperature and pressure conditions (always set to $0.85 \mathrm{~atm}$ ). Only the species with mole fractions greater than $1 \times 10^{-3}$ were discussed, including generally $\mathrm{H}_{2}, \mathrm{CO}, \mathrm{CO}_{2}$, $\mathrm{H}_{2} \mathrm{O}$ and char, as neither $\mathrm{CH}_{4}$ nor heavier gases were found at temperatures higher than $1200{ }^{\circ} \mathrm{C}$.

\section{RESULTS AND DISCUSSION}

In total, 12 solar runs were conducted (Table 2). Except for runs \#3 and \#4, they were all planned in pairs (same operating conditions for both direct and indirect heating modes). The set points for wood ( 1.2 to $1.4 \mathrm{~g} / \mathrm{min}$ ), steam ( 0 to $0.25 \mathrm{~g} / \mathrm{min}$ ) and oxygen ( 0 to $0.38 \mathrm{NL} / \mathrm{min}$ ) flow rates are given in Table 2. They were often changed during operation in order to observe dynamic impacts on the evolution of syngas production. At the beginning of all runs, the temperature measured in the cavity was stabilized at a nominal value (initial $\mathrm{T}_{3}$ temperature) by adjusting the solar power supply (via partial closure of the trapdoor shutter below the reactor). Gasification was then performed under a fixed solar power input, except for runs \#11 and \#12 that featured a partial trapdoor closure (for cutting the sunlight source by $40 \%$ ) to simulate a decrease of the solar power input (e.g., simulation of passing clouds).

Carbon conversion efficiencies and cold gas efficiencies are given in Table 2. These values were calculated over the entire duration of runs, which includes all transient regimes and interruption periods. They thus provide a performance indication for the whole solar experiments. The carbon conversion efficiency (CCE) corresponds to the fraction of carbon atoms injected in the form of biomass that ends in the syngas in the form of $\mathrm{CO}, \mathrm{CO}_{2}, \mathrm{CH}_{4}$ and gas hydrocarbons (mainly $\mathrm{C}_{2} \mathrm{H}_{2}$ and $\mathrm{C}_{2} \mathrm{H}_{4}$ ). $\mathrm{CCE}$ inferior to unity is explained by char remaining unconverted, and by thin char particles entrained by the gas flow and filtered. The former carbon conversion loss reflects the incompleteness of the gasification reaction, while the latter one is due to the gasifier design that leads some particles to escape the cavity before their full conversion. The cold gas efficiency (CGE) is the ratio between syngas and biomass LHV (lower heating value, $\mathrm{MJ} / \mathrm{kg}$ ) multiplied by their respective masses. It measures how well the biomass is converted into syngas and quantifies the improvement (if higher than 1) of the calorific value between the initial feedstock and the produced fuel. Finally, the solar-tofuel energy conversion efficiency was calculated, as defined in Equation 8 [25]. Unlike CGE, it includes at denominator the total solar energy absorbed by the gasifier during the biomass injection periods. Its values ranged between $16 \%$ and $28 \%$.

$$
S F E=\frac{L H V_{\text {syngas }} \cdot m_{\text {syngas }}}{Q_{\text {solar }}+L H V_{\text {feedstock }} \cdot m_{\text {feedstock }}}
$$

Table 2. Operating conditions and overall reactor performance for the solar gasification runs.

\begin{tabular}{|c|c|c|c|c|c|c|c|c|}
\hline$\underset{\#}{\text { Run }}$ & $\begin{array}{c}\text { Heating } \\
\text { mode }\end{array}$ & $\begin{array}{c}\text { Initial } \mathbf{T}_{3} \\
\text { temperature }\left[{ }^{\circ} \mathbf{C}\right]\end{array}$ & $\begin{array}{l}\text { Wood flow } \\
\text { rate }[\mathrm{g} / \mathrm{min}]\end{array}$ & $\begin{array}{l}\text { Steam flow } \\
\text { rate }[\mathrm{g} / \mathrm{min}]\end{array}$ & $\begin{array}{c}\text { Oxygen flow } \\
\text { rate }[\mathrm{NL} / \mathrm{min}]\end{array}$ & CCE & CGE & SFE \\
\hline 1 & Direct & 1215 & 1.2 & 0 & $0.1-0.25-0.38$ & $81.6 \%$ & $65.0 \%$ & - \\
\hline 2 & Indirect & 1190 & 1.2 & 0 & $\begin{array}{c}0.25-0.38- \\
0.1-0.25-0.38 \\
\end{array}$ & $78.7 \%$ & $60.1 \%$ & - \\
\hline 3 & Indirect & 1265 & 1.2 & 0 & 0 & $35.4 \%$ & $46.8 \%$ & - \\
\hline 4 & Indirect & 1205 & $\begin{array}{l}1.2 \\
1.4 \\
\end{array}$ & $\begin{array}{c}0 \\
0.2 \\
\end{array}$ & 0.25 & $80.7 \%$ & $72.4 \%$ & - \\
\hline 5 & Direct & 1200 & $\begin{array}{l}1.2 \\
1.4\end{array}$ & 0.2 & $\begin{array}{c}0 \\
0.25\end{array}$ & $82.9 \%$ & $78.6 \%$ & $17.1 \%$ \\
\hline 6 & Indirect & 1180 & $\begin{array}{l}1.2 \\
1.4\end{array}$ & 0.2 & $\begin{array}{c}0 \\
0.25\end{array}$ & $82.0 \%$ & $77.3 \%$ & $18.7 \%$ \\
\hline 7 & Direct & 1315 & $\begin{array}{l}1.2 \\
1.4\end{array}$ & 0.2 & $\begin{array}{c}0 \\
0.25\end{array}$ & $83.6 \%$ & $97.4 \%$ & $20.6 \%$ \\
\hline 8 & Indirect & 1305 & 1.2 & 0.2 & 0 & $81.4 \%$ & $86.1 \%$ & $18.9 \%$ \\
\hline
\end{tabular}




\begin{tabular}{|c|c|c|c|c|c|c|c|c|}
\hline & & & 1.4 & & 0.25 & & & \\
\hline 9 & Direct & 1215 & 1.4 & 0.2 & 0.25 & $83.7 \%$ & $82.4 \%$ & $23.6 \%$ \\
\hline 10 & Indirect & 1215 & 1.4 & 0.2 & 0.25 & $86.2 \%$ & $81.6 \%$ & $15.6 \%$ \\
\hline 11 & Direct & 1335 & $\begin{array}{l}1.2 \\
1.4 \\
\end{array}$ & 0.2 & $\begin{array}{c}0 \\
0.25\end{array}$ & $86.8 \%$ & $99.8 \%$ & $27.4 \%$ \\
\hline 12 & Indirect & 1325 & $\begin{array}{l}1.2 \\
1.4\end{array}$ & 0.2 & $\begin{array}{c}0 \\
0.25\end{array}$ & $88.3 \%$ & $100.0 \%$ & $28.3 \%$ \\
\hline
\end{tabular}

First of all, experimental results focused on the impact of oxygen flow rate on syngas quality (runs \#1 and \#2). Results obtained with different combinations of $\mathrm{H}_{2} \mathrm{O}$ and $\mathrm{O}_{2}$ were also compared (runs \#3 and \#4). Then, the transition from allothermal to hybrid solar-autothermal operation was studied under constant solar power input (runs \#5 to \#8 at several operating temperatures), and continuous hybrid gasification was carried out to assess the differences between direct and indirect heating modes (runs $\# 9$ and \#10). Finally, two allothermal-hybrid runs under both direct and indirect heating were performed while simulating a drop of solar power input (runs \#11 and \#12). A summary of the experimental results is given in Supplementary Material (Table S.1).

\subsection{Impact of oxygen injection flow rate}

In runs $\# 1$ and $\# 2$, syngas was produced under several $\mathrm{O}_{2}$ flow rates $(0.1,0.25$, and $0.38 \mathrm{NL} / \mathrm{min})$. Experiments were carried out under a very stable DNI (maximum variation of $1.7 \%$ ) at $\sim 1200^{\circ} \mathrm{C}$, with a mean solar power input of $0.76 \mathrm{~kW}_{\mathrm{th}}$. Three and five wood-oxygen injections were performed in direct and indirect heating modes respectively. Between injections, 3 to 5-minute interruptions of the screw driver were set to ensure consumption of the accumulated char by the continuous oxygen stream. Figure 2 shows the output volume flow rates of the main syngas components, measured during the three first injection periods of run \#2. The entire evolution curves for runs \#1 and \#2 are provided in Figure S.1 and Figure S.2, respectively. In all cases, the output flow rate of $\mathrm{O}_{2}$ reached zero during biomass injection periods (while both $\mathrm{H}_{2}$ and $\mathrm{CO}$ are produced). In contrast, when wood injection was stopped, the slowly decreasing $\mathrm{CO}_{2}$ and slowly increasing $\mathrm{O}_{2}$ flow rates indicated that some remaining char was burnt. Sharper changes of the output $\mathrm{O}_{2}$ flow rates (increase at $10 \mathrm{~min}$ and decrease at 19 min, Figure 2) were due to the change of the input flow rate. Besides, the more $\mathrm{O}_{2}$ was injected, the more $\mathrm{CO}_{2}$ was produced (up to $0.3 \mathrm{NL} / \mathrm{min}$ at the highest $\mathrm{O}_{2}$ injection rate). The production rate of $\mathrm{CH}_{4}$ rather tended to decrease with increasing $\mathrm{O}_{2}$ flow rate. The total yields of produced species were calculated for thorough comparison between all injection periods, and plotted in Figure 3.

To calculate the gas production yields (per unit mass of dry feedstock), the mass of wood provided during each injection was corrected pro rata the distribution of output gas masses. Indeed, the wood injection rate tended to decrease over time even though the screw driver was operated at a constant rate. This occurred progressively while the hopper was emptying, which caused the actual $\mathrm{O}_{2}: \mathrm{C}$ ratios to become progressively greater than the expected values. The actual $\mathrm{O}_{2}: \mathrm{C}$ ratios were thus calculated a posteriori: a mass balance was performed for each injection period to determine the specific gas yields (Figure 3) and reactor efficiencies (Figure 4-b). It appeared that the $\mathrm{CO}_{2}$ yield increased proportionally to the $\mathrm{O}_{2}: \mathrm{C}$ ratio, reaching up to $18.5 \mathrm{mmol} / \mathrm{g}_{\text {wood,dry }}$ at a ratio of 0.58 (indirect heating). On the contrary, the quantities of $\mathrm{H}_{2}, \mathrm{CO}, \mathrm{CH}_{4}$ and $\mathrm{C}_{2} \mathrm{H}_{\mathrm{m}}$ decreased when the $\mathrm{O}_{2}$ injection rate increased. For instance, in direct heating mode, the $\mathrm{H}_{2}$ and $\mathrm{CO}$ yields ranged from 20 to 10 $\mathrm{mmol} / \mathrm{g}_{\text {wood,dry }}\left(\mathrm{H}_{2}\right)$ and from 21 to $17 \mathrm{mmol} / \mathrm{g}_{\text {wood,dry }}(\mathrm{CO})$ for $\mathrm{O}_{2}: \mathrm{C}$ ranging from 0.14 to 0.47 . 


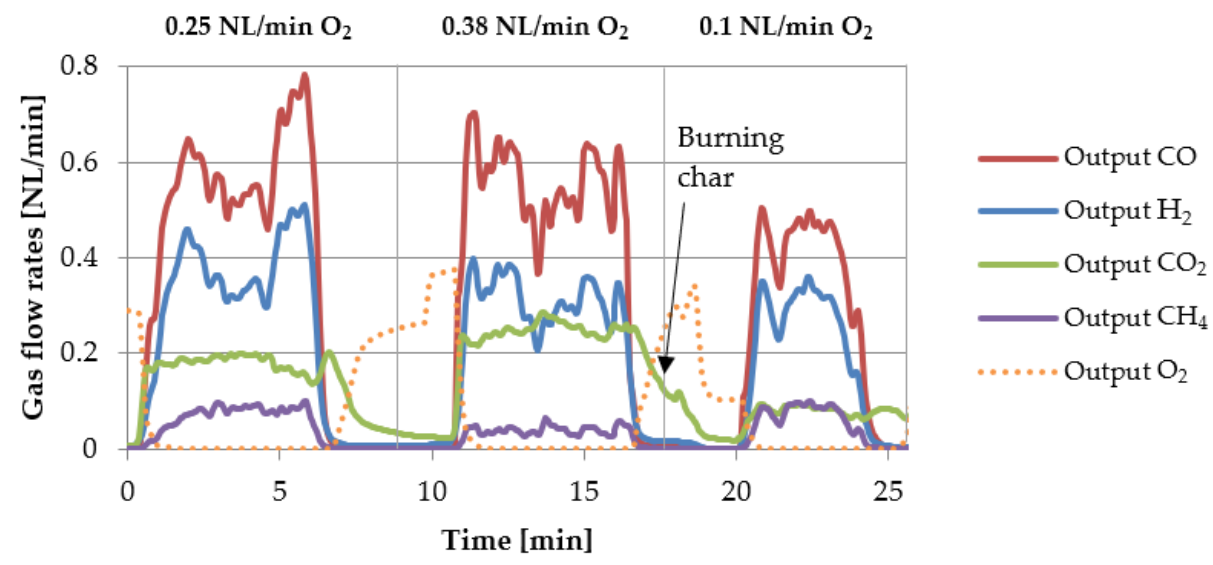

Figure 2. Flow rates of syngas components measured under different $\mathrm{O}_{2}$ injection rates (run \#2).

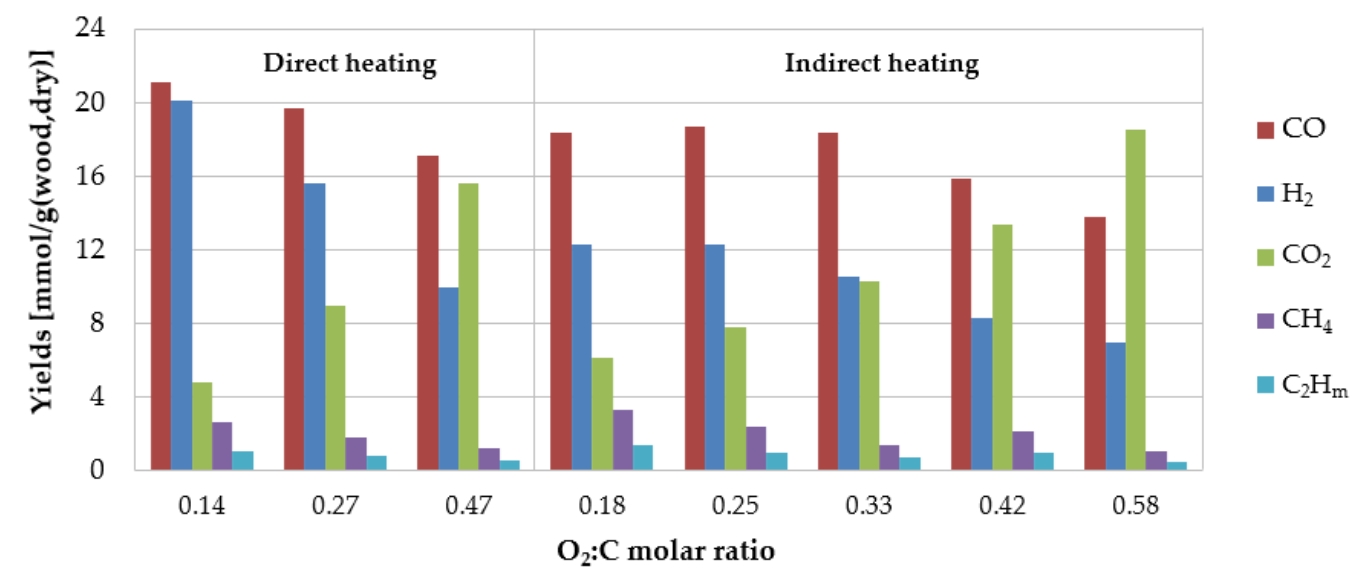

Figure 3. Yields of syngas components measured under increasing $\mathrm{O}_{2}: \mathrm{C}$ molar ratios, in direct (run \#1) and indirect (run \#2) heating modes.

The mole fractions of $\mathrm{H}_{2}, \mathrm{CO}$, and $\mathrm{CO}_{2}$ (dried syngas) are plotted in Figure 4-a as a function of the $\mathrm{O}_{2}: \mathrm{C}$ ratio, and they are compared to the fractions calculated at TE at $1200{ }^{\circ} \mathrm{C}$. Calculations show that at equilibrium, when the oxidant quantity is high enough to gasify all the char $\left(\mathrm{O}_{2}: \mathrm{C}>0.09\right), \mathrm{CO}_{2}$ is produced in growing quantities while both $\mathrm{H}_{2}$ and $\mathrm{CO}$ fractions decrease simultaneously. The measured $\mathrm{H}_{2}$ and $\mathrm{CO}$ mole fractions followed the decreasing trends predicted by TE, with $\mathrm{CO}$ fractions remaining steady for $\mathrm{O}_{2}: \mathrm{C}$ values between 0.18 and 0.33 (as seen in Figure 3 in indirect heating mode). The $\mathrm{H}_{2}$ and $\mathrm{CO}$ mole fraction measurements were lower than values computed at TE, whereas $\mathrm{CO}_{2}$ mole fractions stood far above TE predictions. These measured $\mathrm{CO}_{2}$ fractions were distributed on a trend line of slope $0.76\left(\mathrm{R}^{2}=0.993\right)$ passing through the origin of the graph. The comparison between TE and experimental data showed that combustion was not well represented by thermodynamics: the systematic absolute discrepancy was the result of reaction kinetic limitations. In Figure 4-b, the measured CGE values are also plotted in a single $\mathrm{O}_{2}: \mathrm{C}$ axis. Another clear trend was observed, as the CGE decreased linearly with increasing $\mathrm{O}_{2}: \mathrm{C}$ ratio (function $\mathrm{y}=1.02-1.09 \mathrm{x}$, $\mathrm{R}^{2}=0.940$ ). As a result, the impact of $\mathrm{O}_{2}: \mathrm{C}$ ratio on both $\mathrm{CO}_{2}$ emissions and CGE could precisely be assessed, which might provide precious indications for reactor design and control. 

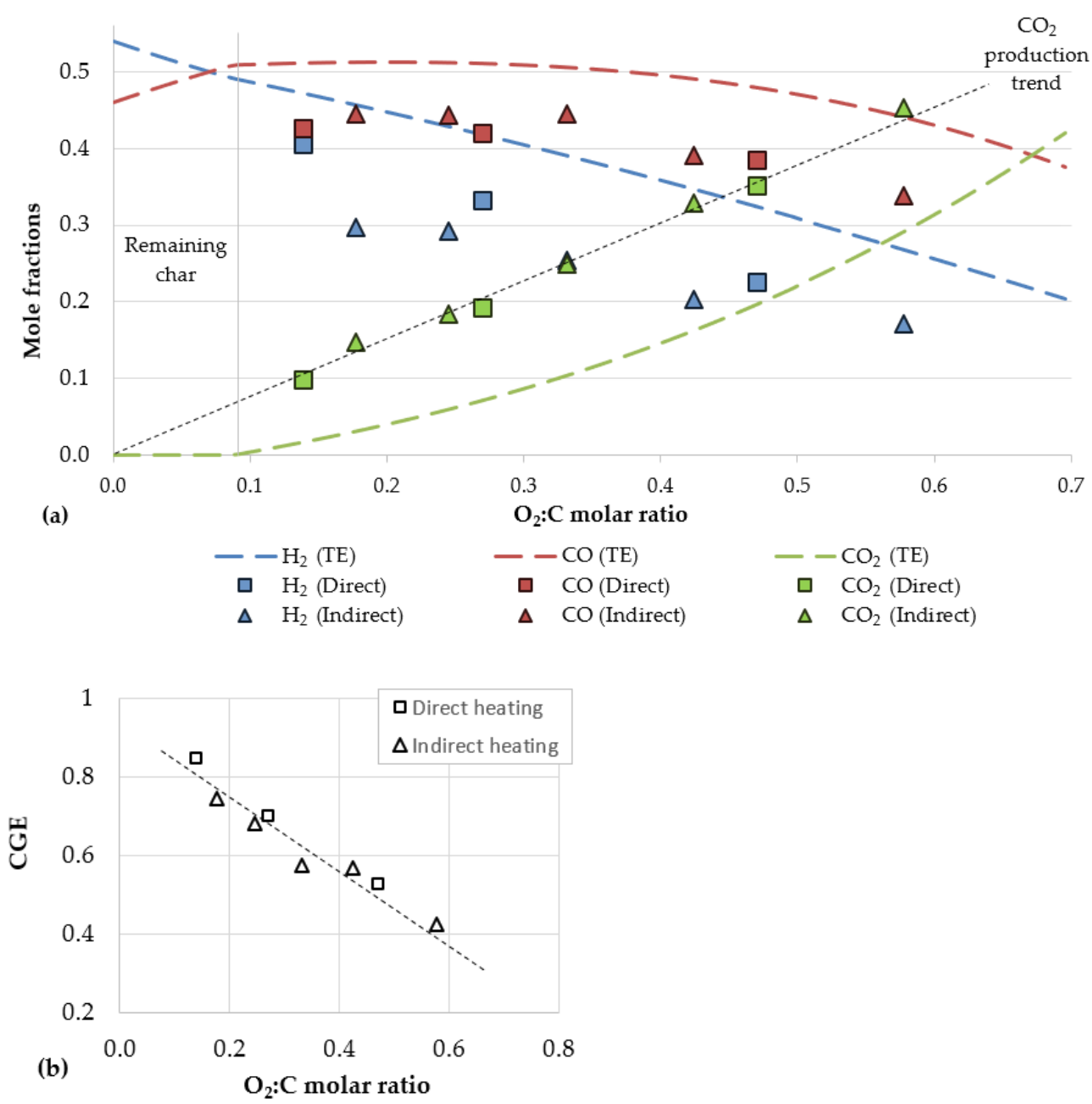

Figure 4. (a) Mole fractions of $\mathrm{H}_{2}, \mathrm{CO}$, and $\mathrm{CO}_{2}$ measured under increasing $\mathrm{O}_{2}: \mathrm{C}$ ratios, in direct (run \#1, squares) and indirect (run \#2, triangles) heating modes, compared with values calculated at $\mathrm{TE}\left(1200{ }^{\circ} \mathrm{C}\right.$, dashed lines). (b) CGE measured under increasing $\mathrm{O}_{2}: \mathrm{C}$ ratios.

A dynamic assessment of the reactor thermal performance is provided in Figure 5, showing the time evolution of the temperatures $\mathrm{T}_{\text {pyro }}$ (corresponding to solid phase for direct heating mode in Figure 5-a; and emitter plate for indirect mode in Figure 5-b), $\mathrm{T}_{2}$ (reactor wall) and $\mathrm{T}_{3}$ (cavity). When wood was injected, most of temperatures rose quickly because of combustion. The temperature measured by the pyrometer inside the cavity (direct heating mode, Figure 5-a) always increased by at least $100{ }^{\circ} \mathrm{C}$ with $\mathrm{O}_{2}$, confirming that a hot flame appeared regardless of the quantity of oxygen injected. The $\mathrm{T}_{3}$ measurement increased when the oxygen injection rate was 0.25 or $0.38 \mathrm{NL} / \mathrm{min}$, whereas it slightly decreased at $0.1 \mathrm{NL} / \mathrm{min}$. Thus, there exists a minimal amount of $\mathrm{O}_{2}$ required to heat the reactor cavity properly. At $0.25 \mathrm{NL} / \mathrm{min}, \mathrm{T}_{3}$ rose by $60{ }^{\circ} \mathrm{C}$ in direct heating mode versus $30{ }^{\circ} \mathrm{C}$ in indirect heating mode. At $0.38 \mathrm{NL} / \mathrm{min}$, it rose by $150{ }^{\circ} \mathrm{C}$ in direct heating mode versus $70{ }^{\circ} \mathrm{C}$ in indirect heating mode. Direct heating therefore appeared more advantageous regarding thermal performances. As for $\mathrm{T}_{2}$, it increased significantly only when $0.38 \mathrm{NL} / \mathrm{min}$ of $\mathrm{O}_{2}$ was injected (until $+200{ }^{\circ} \mathrm{C}$ in direct heating mode and $+50{ }^{\circ} \mathrm{C}$ in indirect heating mode), revealing that the quantity of $\mathrm{O}_{2}$ necessary to efficiently heat the reactor walls was higher than $0.25 \mathrm{NL} / \mathrm{min}$.

In summary, the more oxygen was added, the better the entire reactor was heated. It appeared that combustion primarily affected the temperature in the spout region, which highlights a local heating of the reactor. This heating mode (autothermal) thus differed from the solar heating mode (by radiation) which was mainly directed toward the particles and reactor walls. 

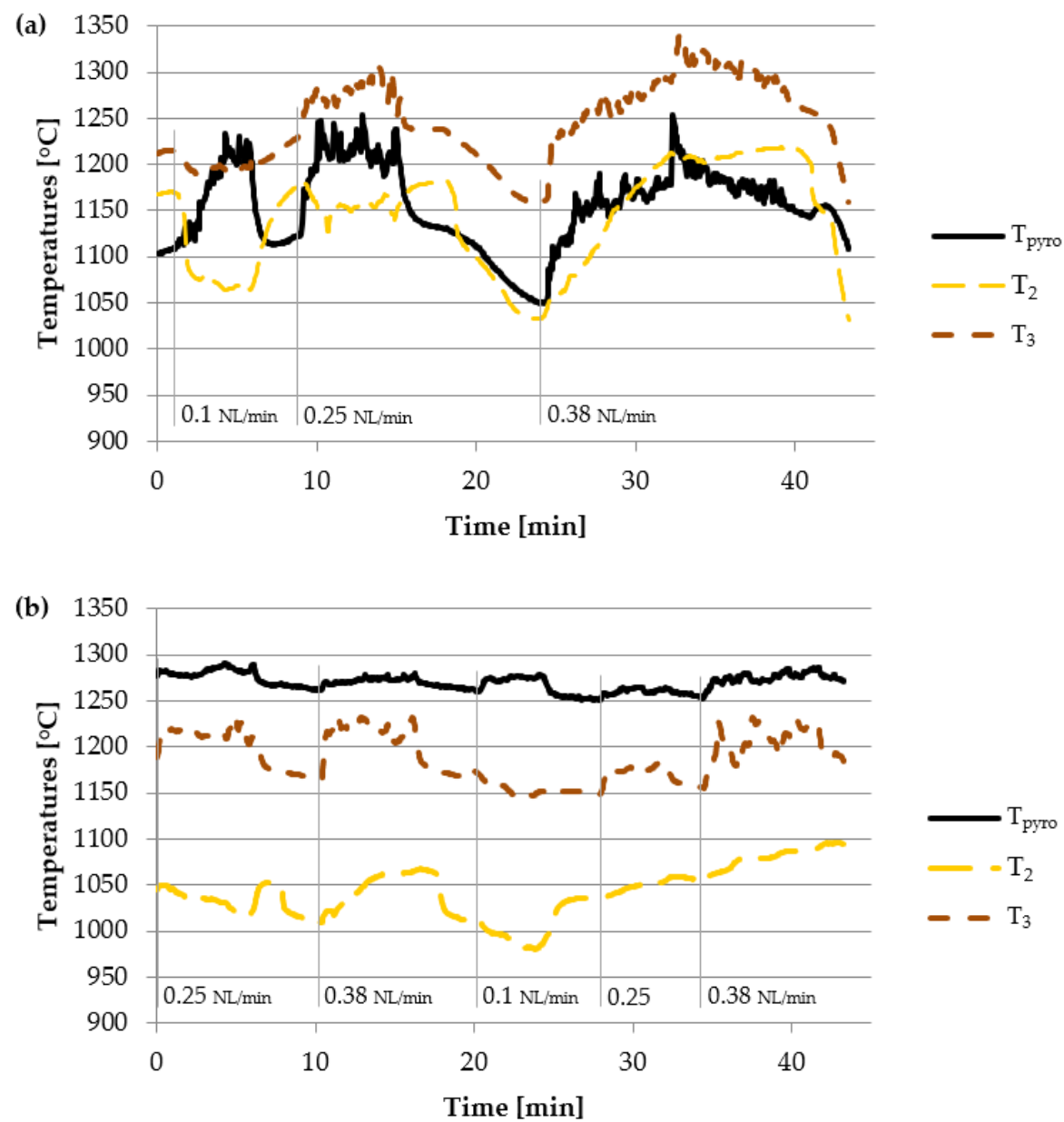

Figure 5. Temperatures evolution measured under different $O_{2}$ injection rates in (a) direct heating mode (run \#1) and (b) indirect heating mode (run \#2).

\subsection{Impact of the combination of oxidizing agents}

The effect of oxidizing gas composition on output syngas yields and reactor efficiency was investigated. It was first unraveled via gasification tests performed with only steam or oxygen injection, and compared with a test featuring no oxidant injection at all (pyrolysis case). Hybrid gasification was then assessed by injecting both $\mathrm{H}_{2} \mathrm{O}$ and $\mathrm{O}_{2}$. Measurements were performed under a similar cavity temperature $\left(\sim 1240{ }^{\circ} \mathrm{C}\right)$ and in indirect heating mode. A summary of experimental conditions is reported in Table 3. The input flow rates of biomass (B), steam (S), and oxygen (O) are given, as well as the corresponding steam/biomass and equivalence ratios (ratios between proportions injected in the reactor and stoichiometric proportions of Equations 1 and 2, respectively). $\mathrm{H}_{2} \mathrm{O}$ was always provided in slightly over-stoichiometric quantities. In contrast, oxygen was provided in highly under-stoichiometric quantities, as only $0.2 \mathrm{~g} / \mathrm{min}$ of wood was intended to be burnt.

Table 3. Gasification conditions for various mixtures of oxidizing agent

\begin{tabular}{cccccc}
\hline $\begin{array}{c}\text { Type of } \\
\text { oxidant }\end{array}$ & $\begin{array}{c}\text { Wood flow } \\
\text { rate }[\mathbf{g} / \mathbf{m i n}]\end{array}$ & $\begin{array}{c}\text { Steam flow } \\
\text { rate }[\mathbf{g} / \mathbf{m i n}]\end{array}$ & $\begin{array}{c}\text { Oxygen flow } \\
\text { rate }[\mathbf{N L} / \mathbf{m i n}]\end{array}$ & $\begin{array}{c}(\mathbf{S} / \mathbf{B}) /(\mathbf{S} / \mathbf{B})_{\text {st }} \\
\text { ratio }\end{array}$ & $\begin{array}{c}\text { Equivalence ratio } \\
(\mathbf{B} / \mathbf{O}) /(\mathbf{B} / \mathbf{O})_{\text {st }}\end{array}$ \\
\hline$\varnothing$ & 1.2 & 0 & 0 & 0.43 & \\
\hline $\mathrm{H}_{2} \mathrm{O}$ & 1.2 & 0.2 & 0 & 1.24 & \\
\hline $\mathrm{O}_{2}$ & 1.2 & 0 & 0.25 & 0.43 & 4.31 \\
\hline $\mathrm{H}_{2} \mathrm{O}+\mathrm{O}_{2}$ & 1.4 & 0.2 & 0.25 & 1.12 & 5.03 \\
\hline
\end{tabular}


Experimental conditions are summed up in Figure 6, and the lines of constant $\mathrm{H}_{2}$ : $\mathrm{CO}$ ratio and CGE calculated at TE are plotted in the $\left(\mathrm{O}_{2}: \mathrm{C} ; \mathrm{H}_{2} \mathrm{O}: \mathrm{C}\right)$ plane. Because of the biomass moisture content, the minimal $\mathrm{H}_{2} \mathrm{O}: \mathrm{C}$ ratio equals 0.134 . The domain where char cannot be totally converted is found below the red line. It shows that either $0.14 \mathrm{~g} / \mathrm{min}$ of steam or $0.9 \mathrm{NL} / \mathrm{min}$ of oxygen are necessary to gasify all the char at equilibrium. Then, addition of oxygen enables combustion, and addition of steam increases the $\mathrm{H}_{2}$ :CO ratio (via steam shifting). For example, TE predicts that the CGE undergoes an absolute decrease of 0.12 when $\mathrm{O}_{2}: \mathrm{C}$ rises from 0.1 to 0.2 , and that the $\mathrm{H}_{2}: \mathrm{CO}$ ratio benefits from an absolute increase of 0.05 when $\mathrm{H}_{2} \mathrm{O}: \mathrm{C}$ rises from 0.3 to 0.4 . Experimental series were performed to validate these theoretical trends.

Data used in this section stem from runs \#2 ( $\mathrm{O}_{2}$-only case), \#3 (pyrolysis case), \#4 (hybrid case), and \#8 $\left(\mathrm{H}_{2} \mathrm{O}\right.$-only case). The corresponding syngas evolution curves are provided in Figures S.2, S.3, S.4, and 6-b. The $\mathrm{O}_{2}: \mathrm{C}$ and $\mathrm{H}_{2} \mathrm{O}: \mathrm{C}$ molar ratios indicated in Figure 6 are the ones calculated back after the experiments, as pointed out in section 2.1. In the hybrid case, the actual values were always much higher than the expected ones because of rapidly decreasing wood injection rates: they reached 0.29 and 0.45 respectively (instead of 0.21 and 0.35 as calculated with the flow rates of Table 3 ).

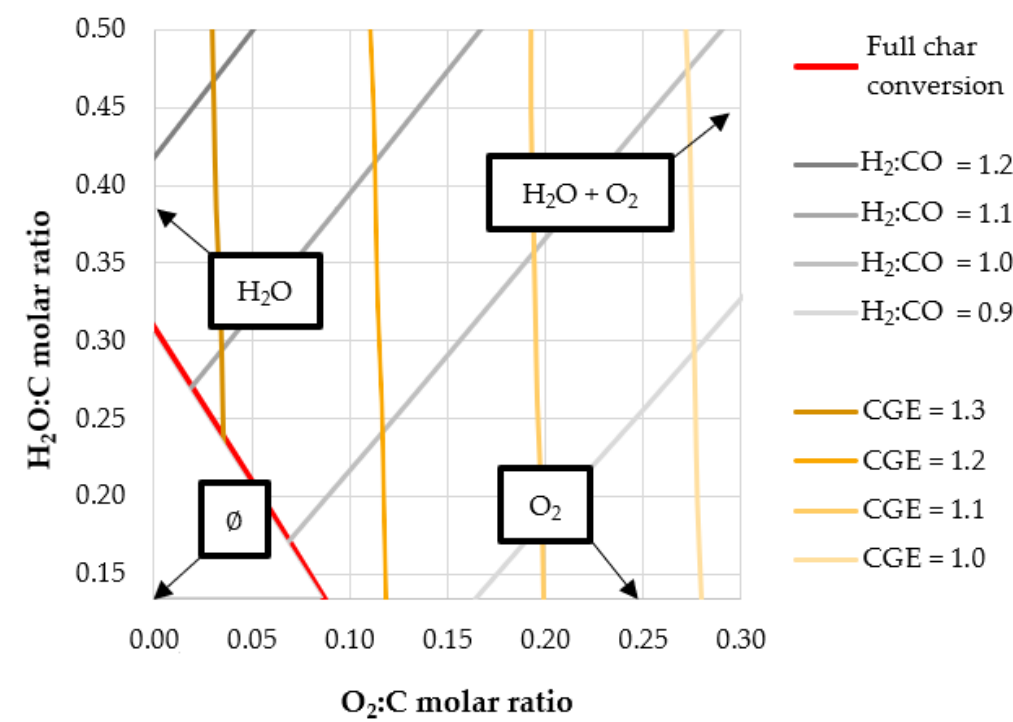

Figure 6. Lines of constant $\mathrm{H}_{2}: \mathrm{CO}$ ratios and CGE, and limit of complete char conversion domain, computed at TE $\left(1200{ }^{\circ} \mathrm{C}\right.$ ). Positions of the experimental runs conditions (pyrolysis, $\mathrm{H}_{2} \mathrm{O}, \mathrm{O}_{2}, \mathrm{H}_{2} \mathrm{O}+\mathrm{O}_{2}$ ) are indicated with arrows.

A comprehensive comparison of the syngas yields and CGE obtained during the four experiments is provided in Figure 7. Firstly, the syngas produced in the pyrolysis case had a similar composition than in the $\mathrm{H}_{2} \mathrm{O}$-only case, but with lower yields (divided by 2.0 to 2.8 ). This was explained by the insufficient $(\mathrm{S} / \mathrm{B}) /(\mathrm{S} / \mathrm{B})_{\mathrm{st}}$ ratio, equaling 0.43 in the pyrolysis case. In other words, only $43 \%$ of the char produced by pyrolysis could be gasified. This loss went with a decrease of the CGE by $53 \%$ (from 0.99 to 0.47 ) between $\mathrm{H}_{2} \mathrm{O}$-only and pyrolysis cases. Meanwhile, the syngas $\mathrm{H}_{2}: \mathrm{CO}$ ratio equaled 1.25 in $\mathrm{H}_{2} \mathrm{O}$-only case versus only 1.15 in pyrolysis case, showing that excess steam might have facilitated water-gas shift (Equation 6). Secondly, between pyrolysis and $\mathrm{O}_{2}$-only cases, the $\mathrm{CO}$ yield increased whereas the $\mathrm{H}_{2}$ yield remained the same. Both yields were expected to increase because of complete char conversion, but $\mathrm{H}_{2}$ yield was not increased because it might have been partially consumed by combustion with $\mathrm{O}_{2}$. The CGE was much higher ( 0.68 instead of 0.47 in the pyrolysis case), at the expense of increased $\mathrm{CO}_{2}$ production yield $\left(7.8 \mathrm{mmol} / \mathrm{g}_{\text {wood,dry }}\right.$ instead of 0.9 $\mathrm{mmol} / \mathrm{g}_{\text {wood,dry }}$ in the pyrolysis case). Finally, by comparing between $\mathrm{O}_{2}$-only and hybrid cases, the additional injection of water and biomass rose the $\mathrm{H}_{2}$ yield from 12.3 to $14.8 \mathrm{mmol} / \mathrm{g}_{\text {wood,dry }}$ and the

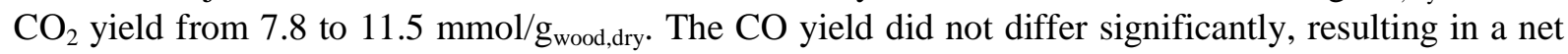
increase of the $\mathrm{H}_{2}: \mathrm{CO}$ ratio from 0.66 to 0.81 . 
These results provided insights into the impact of the various oxidizing agents. Tendencies found at TE (Figure 6) were validated by experimental data (Figure 7). As predicted, the highest $\mathrm{H}_{2}: \mathrm{CO}$ ratio and CGE were measured in the $\mathrm{H}_{2} \mathrm{O}$-only case (1.25 and 0.99 , respectively, while TE predicted values of 1.18 and 1.34). Experiments also confirmed that the $\mathrm{H}_{2}$ :CO ratio during hybrid gasification was higher than during $\mathrm{O}_{2}$-only gasification $(0.81$ versus 0.66$)$ due to the addition of water. Lack of oxidizing agent (pyrolysis case) resulted in remaining char and lower gas yields while $\mathrm{O}_{2}$ injection enabled some heat release by combustion associated with $\mathrm{CO}_{2}$ production.

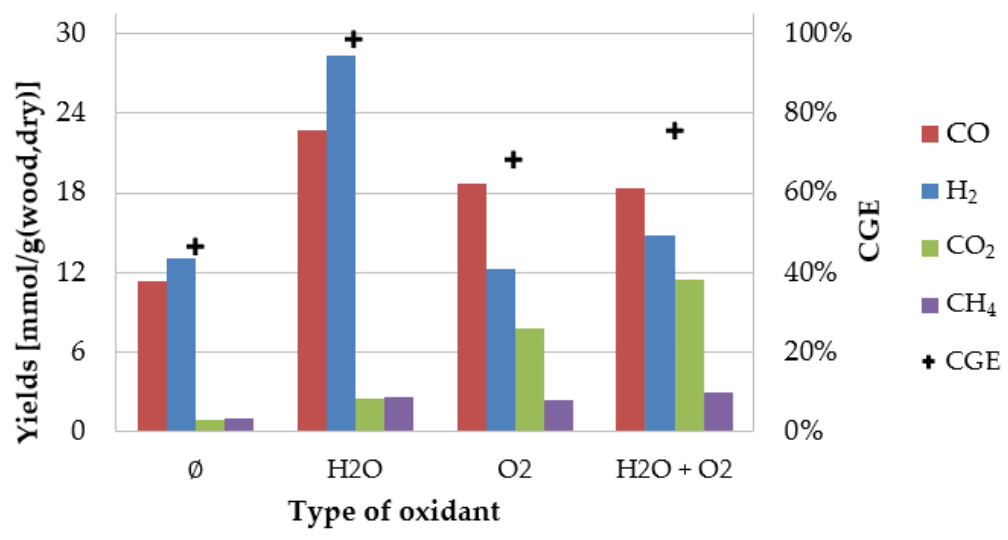

Figure 7. Yields of syngas components and CGE measured with different oxidizing gases (runs \#3, \#8, \#2, and \#4 from left to right).

\subsection{Impact of temperature on hybrid gasification under fixed solar power input}

Runs \#5 to \#8 were performed to investigate the transition between allothermal and hybrid operation under a constant solar power input. Runs \#5 and \#6 started near $1200{ }^{\circ} \mathrm{C}\left(\mathrm{T}_{3}\right.$ measurement $)$ and runs $\# 7$ and \#8 started near $1300{ }^{\circ} \mathrm{C}$. At first, a $1.2 \mathrm{~g} / \mathrm{min}$ feeding rate of beech wood was gasified by a 0.2 $\mathrm{g} / \mathrm{min}$ flow rate of steam (according to Equation 1). After steady state was reached, an additional 0.2 $\mathrm{g} / \mathrm{min}$ feeding rate of wood was provided and intended to be burnt by a $0.25 \mathrm{NL} / \mathrm{min}$ flow rate of oxygen (according to Equation 2). Gasification was carried out in both direct (runs \#5 and \#7) and indirect (\#6 and \#8) heating modes. In Figure 8, the flow rates of produced gases and the reactor temperatures obtained in indirect heating mode are shown (Figure 8-a and Figure 8-b for runs starting at $1200{ }^{\circ} \mathrm{C}$ and $1300{ }^{\circ} \mathrm{C}$, respectively). The curves obtained in direct heating mode (runs \#5 and \#7) are provided in Supplementary Material (Figure S.5 and Figure S.6). In all cases, hybridization was characterized by a rise in the $\mathrm{CO}_{2}$ flow rate, and by the $\mathrm{H}_{2}$ flow rate becoming lower than the $\mathrm{CO}$ one. The $\mathrm{H}_{2}$ and $\mathrm{CO}$ production rates dropped with the depletion of the feedstock in the hopper, but the production of $\mathrm{CO}_{2}$ continued for a few minutes as long as char remained in the cavity.

During allothermal gasification periods, $\mathrm{T}_{2}$ and $\mathrm{T}_{3}$ decreased because of the endothermic reaction occurring in the reactor. This cooling was faster when starting at $1200{ }^{\circ} \mathrm{C}: \mathrm{T}_{2}$ decreased by $105{ }^{\circ} \mathrm{C}$ in 5 minutes in run \#6 versus $65^{\circ} \mathrm{C}$ in 10 minutes in run \#8. During hybrid operation, $\mathrm{T}_{2}$ increased back at a rate of around $6.7^{\circ} \mathrm{C} / \mathrm{min}$. $\mathrm{T}_{3}$ increased continuously in run $\# 8\left(\sim 4.7^{\circ} \mathrm{C} / \mathrm{min}\right)$, but in run \#6 it quickly stagnated around $1200{ }^{\circ} \mathrm{C}$. In both cases, the initial reactor temperatures were recovered when combustion occurred, and $T_{2}$ and $T_{3}$ values could even rise above their nominal values. Similar observations were done in direct heating mode (Figure S.5 and Figure S.6), with $\mathrm{T}_{3}$ reaching back its initial value during hybrid operation. This confirmed the suitability of hybridization to overcome a potential loss of solar power. 
(a)

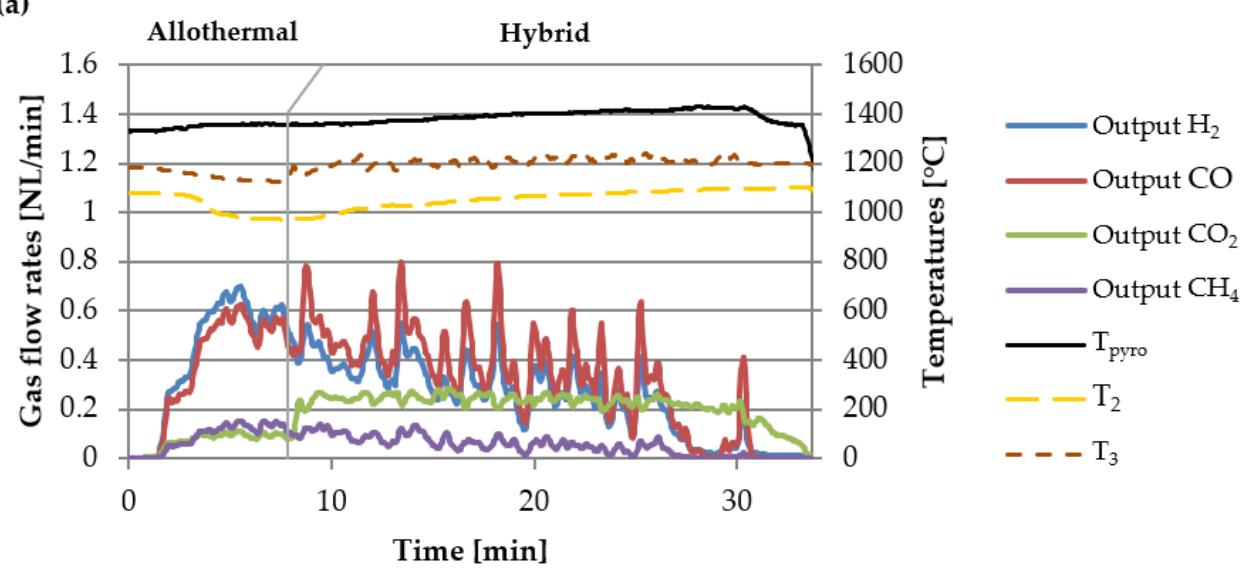

(b)
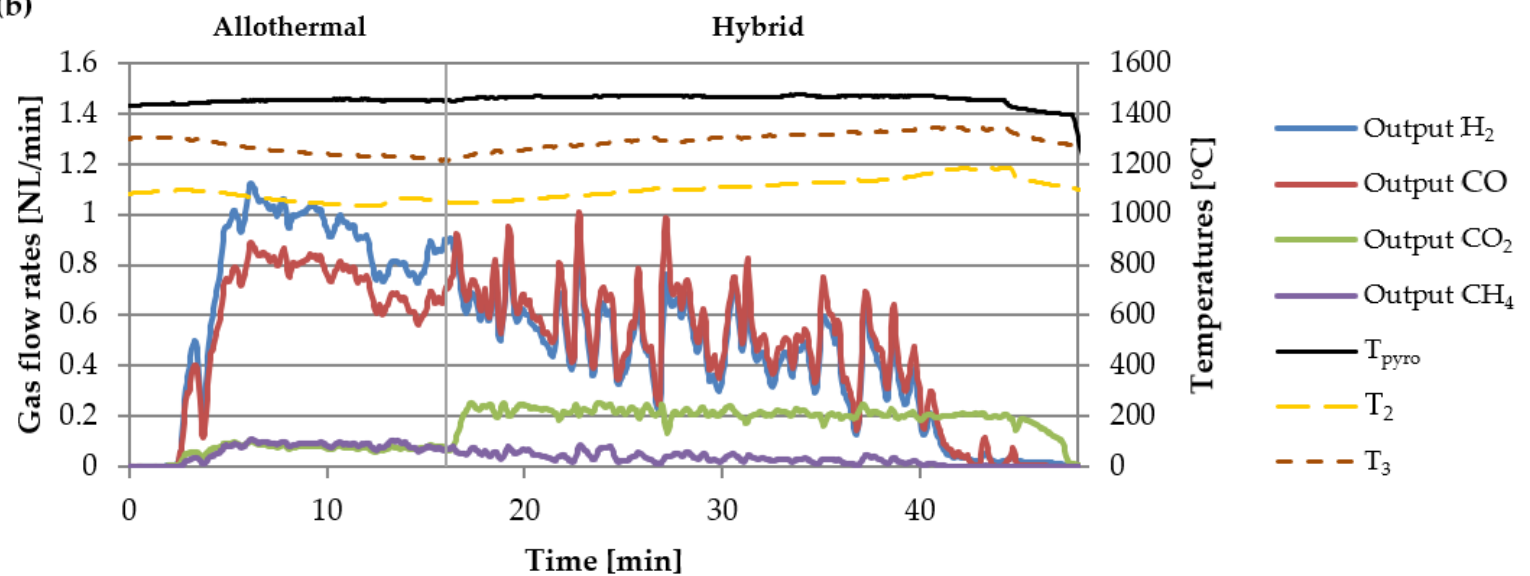

Figure 8. Flow rates of syngas components and temperatures measured during allothermal-hybrid runs, at a starting cavity temperature of (a) $1200{ }^{\circ} \mathrm{C}$ (run \#6) and (b) $1300{ }^{\circ} \mathrm{C}$ (run \#8).

The calculated syngas yields and CGE values are displayed in Figures 9-a $\left(1200{ }^{\circ} \mathrm{C}\right)$ and 9-b $(1300$ ${ }^{\circ} \mathrm{C}$ ) along with TE predictions. Separate mass balances were performed for allothermal and hybrid time periods, in order to provide performance assessments. However, the uncertainty was higher than in Figure 3 and Figure 4-b, since the char accumulated in the cavity during allothermal gasification was not totally consumed before switching to hybrid gasification. Thus, the CGE values and the yields (especially $\mathrm{CO}_{2}$ ) determined in allothermal operation might have been under-estimated by up to $10 \%$ as additional production of gases would be expected from gasification of this remaining char.

Experimental results showed a net decrease of $\mathrm{H}_{2}$ yields between allothermal and hybrid operations (from 22.3 to $13.4 \mathrm{mmol} / \mathrm{g}_{\text {wood,dry }}$ at $1200{ }^{\circ} \mathrm{C}$ and from 28.4 to $19.7 \mathrm{mmol} / \mathrm{g}_{\text {wood,dry }}$ at $1300{ }^{\circ} \mathrm{C}$ in indirect heating mode). The $\mathrm{CO}$ yield decreased as well at $1200{ }^{\circ} \mathrm{C}$, but it almost did not change at $1300{ }^{\circ} \mathrm{C}$. Meanwhile, hybridization caused the measured $\mathrm{CO}_{2}$ yields to increase sharply (from 3.8 to 11.8 $\mathrm{mmol} / \mathrm{g}_{\text {wood,dry }}$ at $1200{ }^{\circ} \mathrm{C}$ and from 2.5 to $10.2 \mathrm{mmol} / \mathrm{g}_{\text {wood,dry }}$ at $1300{ }^{\circ} \mathrm{C}$ in indirect heating mode). The CGE thus decreased between allothermal and hybrid gasification, with a higher loss observed at 1200 ${ }^{\circ} \mathrm{C}$ (from 1.01 to 0.70 in indirect heating mode) than at $1300{ }^{\circ} \mathrm{C}$ (from 0.99 to 0.78 in indirect heating mode). The same trends were observed in direct heating mode, though the performances obtained at $1200{ }^{\circ} \mathrm{C}$ were impaired by the emission of smoke (interruptions of gasification are visible in Figure S.5). Unlike experimental results, the TE predictions were not impacted by an increase of the nominal temperature. Thus, temperature impacted the reaction kinetics but not the system chemical equilibrium. 
All these results allowed to precisely quantify the impact of temperature on the reactor performances in both allothermal and hybrid operating modes. In addition to provide insights into the dynamic transition between these two operation modes both in terms of temperature and species output, they showed that higher temperatures enabled to produce more $\mathrm{H}_{2}$ and $\mathrm{CO}$ with lower amounts of $\mathrm{CO}_{2}$ and $\mathrm{CH}_{4}$, which was due to improved reaction kinetics. High temperatures also enabled to enhance the CGE during hybrid gasification.
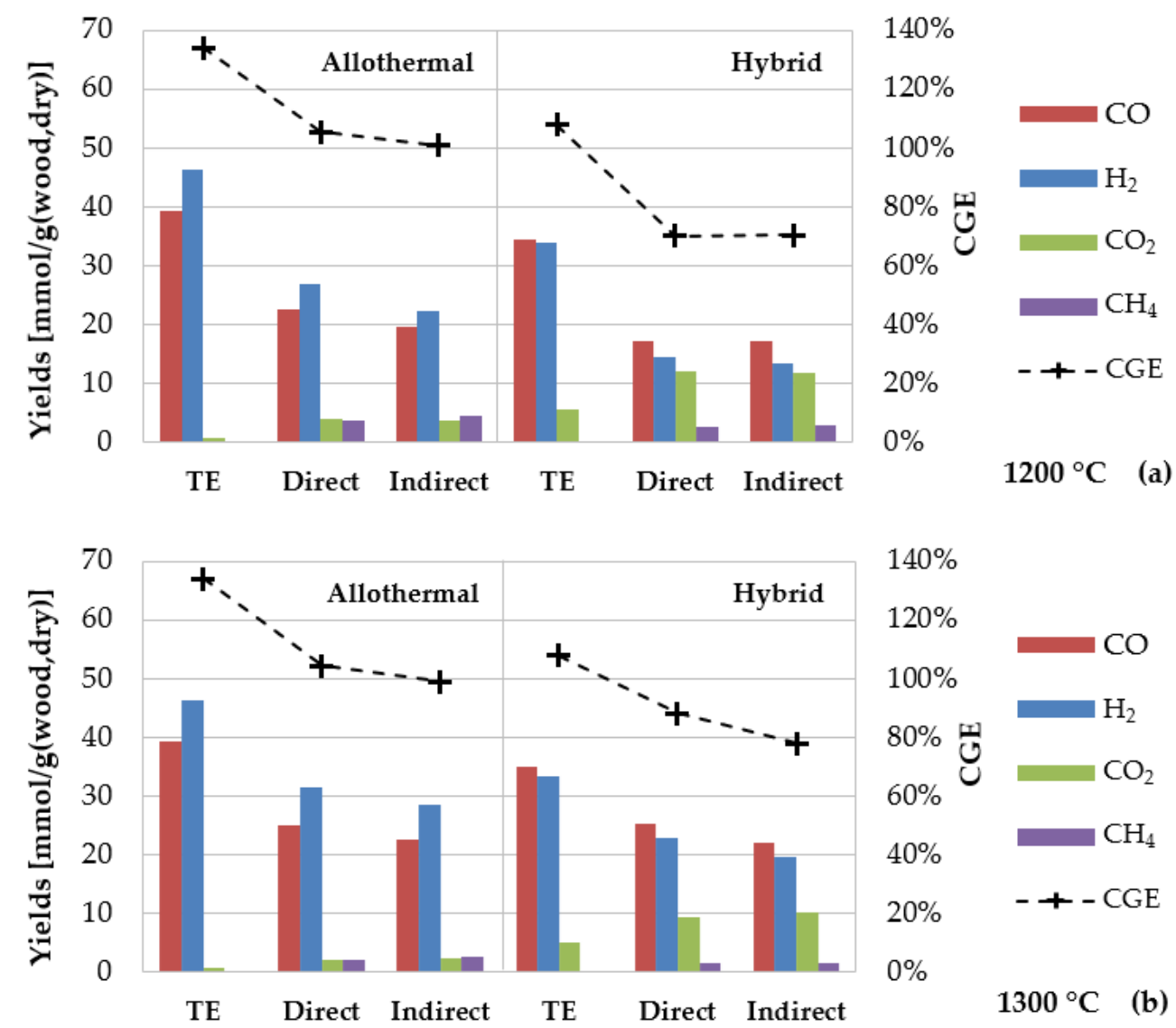

$140 \%$

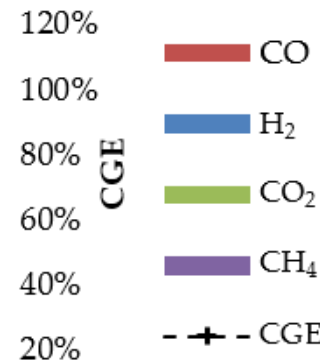

$0 \%$

$1300{ }^{\circ} \mathrm{C} \quad(\mathrm{b})$

Figure 9. Yields of syngas components and CGE measured during allothermal-hybrid runs, and values calculated at TE, at a nominal cavity temperature of (a) $1200{ }^{\circ} \mathrm{C}$ (runs \#5 and \#6) and (b) $1300{ }^{\circ} \mathrm{C}$ (runs \#7 and \#8).

\subsection{Impact of heating mode during continuous hybrid operation}

A first hint on the impact of heating mode was given in section 2.3. Figure 9 showed that a higher production of both $\mathrm{H}_{2}$ and $\mathrm{CO}$ was usually obtained in direct heating mode, resulting in higher CGE values. During allothermal operation at $1300{ }^{\circ} \mathrm{C}$, the CGE was estimated at 1.04 in direct heating mode versus 0.99 in indirect heating mode. During hybrid operation at $1300{ }^{\circ} \mathrm{C}$, it was estimated at 0.88 in direct heating mode versus 0.78 in indirect heating mode. Boujjat et al. [46] indeed demonstrated that direct heating favored solar radiation absorption, with sunlight reaching directly the solid particles and the cavity walls. This experimental and numerical study showed that during allothermal gasification, the reacting bulk solid could locally reach much higher temperatures than the measured ones (they peaked at around $1500{ }^{\circ} \mathrm{C}$ ). However, no comparison between direct and indirect heating modes was performed during hybrid gasification.

Continuous hybrid gasification was performed in runs \#9 and \#10 to precisely assess the gasification performances in direct and indirect heating modes, respectively. The $\mathrm{T}_{3}$ temperature was initially set to $1200{ }^{\circ} \mathrm{C}$ thanks to the controlled opening of the shutter trapdoor. Water steam was then injected continuously in the reactor at a rate of $0.2 \mathrm{~g} / \mathrm{min}$, and oxygen and wood were provided at respective 
flow rates of $0.25 \mathrm{NL} / \mathrm{min}$ and $1.4 \mathrm{~g} / \mathrm{min}$. Steady hybrid operation was thus expected to settle during periods longer than in previous runs. The output gas flow rates and the reactor temperatures of the two continuous runs are given in Figure 10. In both direct (Figure 10-a) and indirect (Figure 10-b) heating modes, the volume flow rates of $\mathrm{H}_{2}$ and $\mathrm{CO}$ reached values around $0.6 \mathrm{NL} / \mathrm{min}$ after 1 minute of wood injection, and then oscillated with unequal amplitudes.

The fluctuations of syngas production rates were particularly noticeable in indirect heating mode (run \#10). The $\mathrm{CO}_{2}$ flow rate evolution, that used to remain steady in direct heating mode, had a much higher standard deviation in indirect heating mode $(0.037 \mathrm{NL} / \mathrm{min}$ instead of $0.007 \mathrm{NL} / \mathrm{min})$. Unsteady $\mathrm{CO}_{2}$ production rate in indirect heating mode was also observed in runs \#6 and \#12, when compared with runs \#5 and \#11, respectively. Such oscillations might be caused by the emitter plate disturbing the gas flow between the cavity and the window, and leading to unexpected variations of the gas residence time.

Meanwhile, the reactor temperatures stabilized after two minutes of injection, and remained steady despite the variations of syngas production rates. $\mathrm{T}_{3}$ rose by $105^{\circ} \mathrm{C}$ in run $\# 9$ and by around $135^{\circ} \mathrm{C}$ in run \#10, and $\mathrm{T}_{2}$ remained lower than or equal to its initial value. This tendency was in accordance with the observations of section 2.1, confirming that hybrid operation was efficient to heat the reaction volume rather than the cavity walls. However, issues of pyrolytic smoke formation occurred. The injection of wood and oxygen was thus stopped during 3 to 5 minutes, once per run, to let the smoke dissipate. Because of these interruptions, steady state operation could not be maintained more than 10 consecutive minutes. Furthermore, gasification could not be recovered after the interruption of run \#10 (indirect heating, Figure 10-b): the wall and emitter plate temperatures kept on decreasing despite the injection of reactants. This altered gasification regime resulted in an altered solar-to-fuel efficiency when compared to direct heating mode ( $16 \%$ instead of $24 \%$ for complete runs, as stated in Table 2). No such gap was found between direct and indirect heating among the other pairs of runs. Anyway, such high values denote that solar power is efficiently exploited during hybrid gasification.

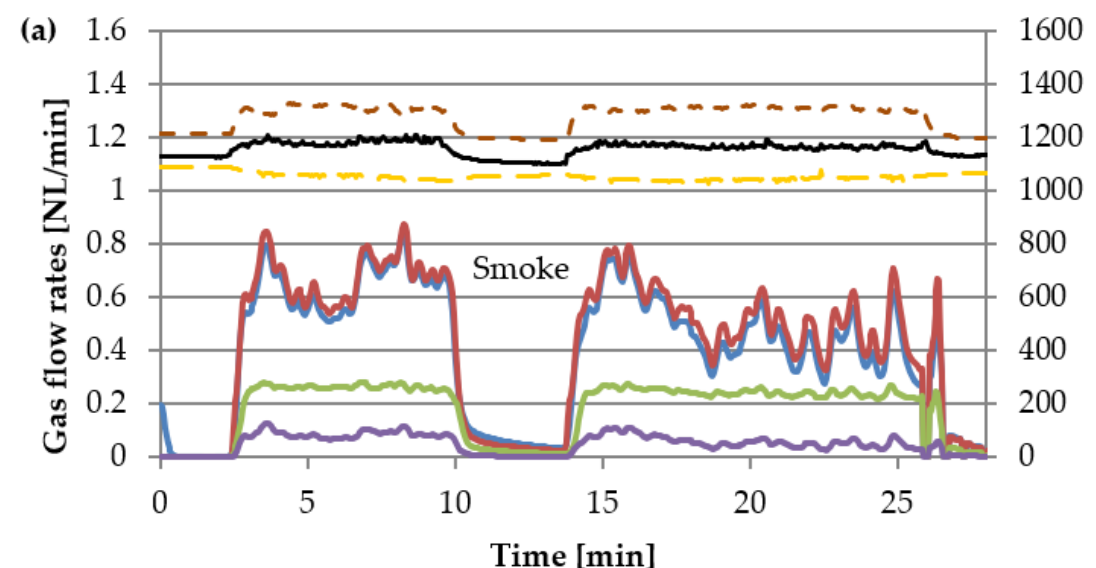

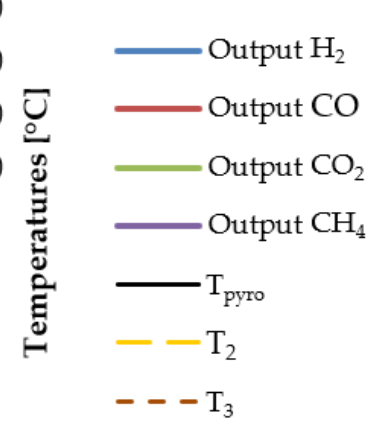



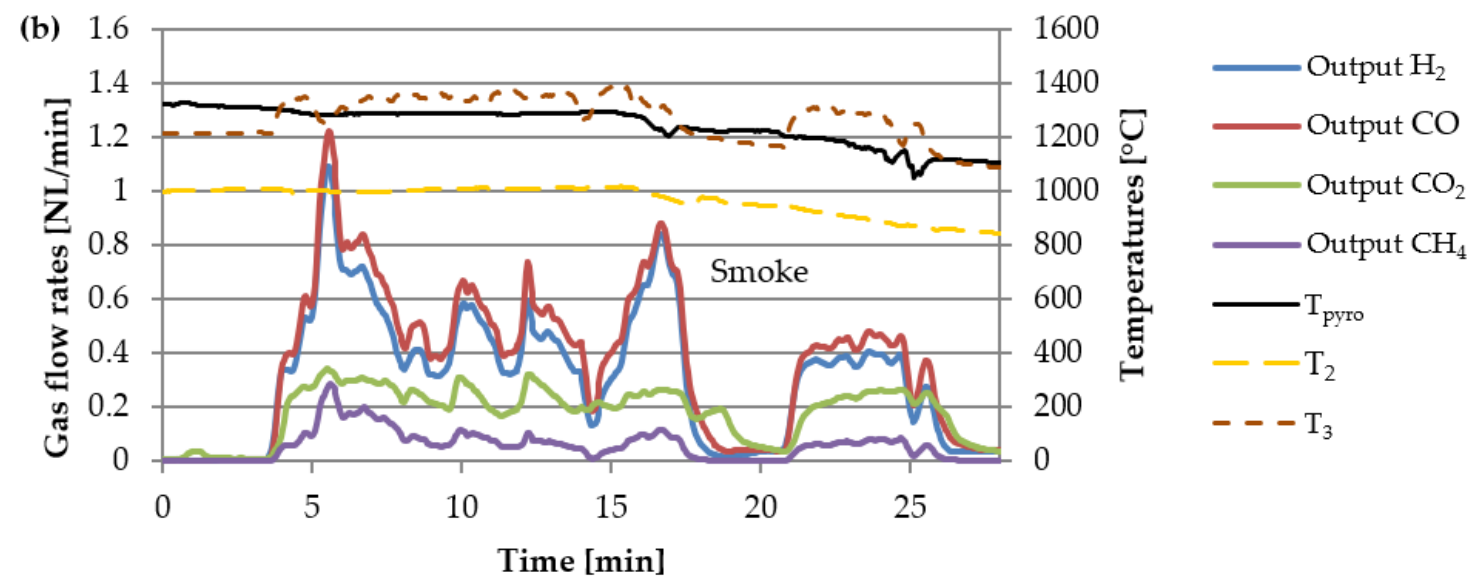

Figure 10. Flow rates of syngas components and temperatures measured during continuous hybrid runs, in (a) direct (run \#9) and (b) indirect (run \#10) heating modes.

Global experimental outcome is summarized in Table 4, providing the syngas yields and reactor efficiencies calculated over the entire runs. Regarding the mass balance, 27.9 and $25.6 \mathrm{~g}$ of wood were injected in runs \#9 and \#10, respectively. In direct heating mode, $12.05 \mathrm{~g}$ of residue (solid particles along with unconverted water) were weighed in the outlet reactor components (tubing, bubbler and filter), leading to a mass balance closure of $96 \%$. Regarding the CCE, it equaled $83.7 \%$ in direct heating mode and $86.2 \%$ in indirect heating mode. The CGE equaled $~ 82 \%$ in both heating modes. However, despite similar CGE values, direct heating mode offered higher $\mathrm{H}_{2}$ and $\mathrm{CO}$ yields and lower $\mathrm{CO}_{2}, \mathrm{CH}_{4}$ and $\mathrm{C}_{2} \mathrm{H}_{\mathrm{m}}$ yields.

These continuous gasification runs confirmed that stable temperatures could be reached during hybrid gasification, with the cavity volume being heated while the walls remained at their initial temperature. The direct heating mode enabled a superior production of both $\mathrm{H}_{2}$ and $\mathrm{CO}$, even if the lower production of $\mathrm{C}_{2} \mathrm{H}_{\mathrm{m}}$ tended to bring the CGE down to the same value than in indirect heating mode. This confirmed that direct heating of the gasifier improved its performance, in addition to ensuring a better stability of the syngas production rate in the lab-scale reactor.

Table 4. Yields of syngas components, energy breakdown (lower heating values and solar energy absorbed by the reactor), and efficiencies measured during continuous hybrid runs (runs \#9 and \#10).

\begin{tabular}{cccccccccccc}
\hline & \multicolumn{4}{c}{ Yields $\left[\mathrm{mmol} / \mathbf{g}_{\text {wood,dry }}\right]$} & \multicolumn{3}{c}{ Energy breakdown [kJ] } & \multicolumn{3}{c}{ Efficiencies } \\
Run & $\mathbf{H}_{\mathbf{2}}$ & $\mathbf{C O}$ & $\mathbf{C O}_{\mathbf{2}}$ & $\mathbf{C H}_{\mathbf{4}}$ & $\mathbf{C}_{\mathbf{2}} \mathbf{H}_{\mathbf{m}}$ & Biomass & Syngas & $\begin{array}{c}\text { Solar } \\
\text { Power }\end{array}$ & $\mathbf{C C E}$ & $\mathbf{C G E}$ & $\mathbf{S F E}$ \\
\hline$\# 9$ & 19.17 & 20.59 & 8.78 & 2.49 & 1.11 & 426 & 351 & 1060 & $83.7 \%$ & $82.4 \%$ & $23.6 \%$ \\
\hline$\# \mathbf{1 0}$ & 16.67 & 19.66 & 9.80 & 3.13 & 1.31 & 391 & 320 & 1656 & $86.2 \%$ & $81.6 \%$ & $15.6 \%$ \\
\hline
\end{tabular}

\subsection{Hybrid gasification after a drop of solar power input}

In this last section, the transition between allothermal and hybrid gasification was performed to compensate for a drop of solar power input and to demonstrate the feasibility of continuous operation with a variation of solar irradiation conditions. The $\mathrm{T}_{3}$ temperature was first stabilized at $\sim 1330{ }^{\circ} \mathrm{C}$, and allothermal operation was started. After steady state was reached, the trapdoor was partially closed, making the solar power drop by $40 \%$ (from $\sim 1200 \mathrm{~W}$ to $\sim 700 \mathrm{~W}$ ). After the trapdoor closure, oxygen and additional wood were injected. Figure 11 shows the evolution of syngas production rates and reactor temperatures, in both direct (run \#11, Figure 11-a) and indirect (run \#12, Figure 11-b) heating modes. In both cases, when the trapdoor was partially closed, all the temperatures decreased 
immediately due to the solar power reduction. When oxygen was added, temperatures evolved as follows:

- $\quad$ The temperature of the wall $\left(\mathrm{T}_{2}\right)$ kept on decreasing slowly despite combustion, reaching a value $200{ }^{\circ} \mathrm{C}$ lower than its initial value. Meanwhile, the temperature of the emitter plate $\left(\mathrm{T}_{\text {pyro }}\right.$ in indirect heating mode, Figure 11-b) decreased slowly until reaching $1400{ }^{\circ} \mathrm{C}$;

- The temperature in the cavity $\left(\mathrm{T}_{3}\right)$ rose by $150{ }^{\circ} \mathrm{C}$ in less than 2 minutes, and then seemed to decrease slowly on the long term. The temperature of the bulk solid $\left(\mathrm{T}_{\text {pyro }}\right.$ in direct heating mode, Figure 11-a) followed the same variations.

The center of the cavity was thus maintained near its initial temperature $\left(\mathrm{T}_{3} \approx 1330{ }^{\circ} \mathrm{C}\right)$ during the 10 minute hybrid period, while the reactor walls tended to cool down because of a lower solar power input. As suggested previously, combustion was suitable to heat the reaction volume very locally, which translated into $\mathrm{T}_{3}$ being maintained despite a cut of $500 \mathrm{~W}$ of the incident solar power. In comparison, combustion of biomass feedstock by $0.25 \mathrm{NL} / \mathrm{min}$ of oxygen would release only $71 \mathrm{~W}$, while combustion of carbon monoxide alone would release a threshold power of $104 \mathrm{~W}$ (versus $88 \mathrm{~W}$ for hydrogen combustion, based on standard enthalpies). Besides, the solar-to-fuel efficiency was calculated over the entire runs, and it equaled $27.4 \%$ and $28.3 \%$ in direct and indirect heating modes, respectively. These values were higher than those of the previous runs, confirming that solar power was suitably exploited despite the cooling of the cavity walls.

(a)

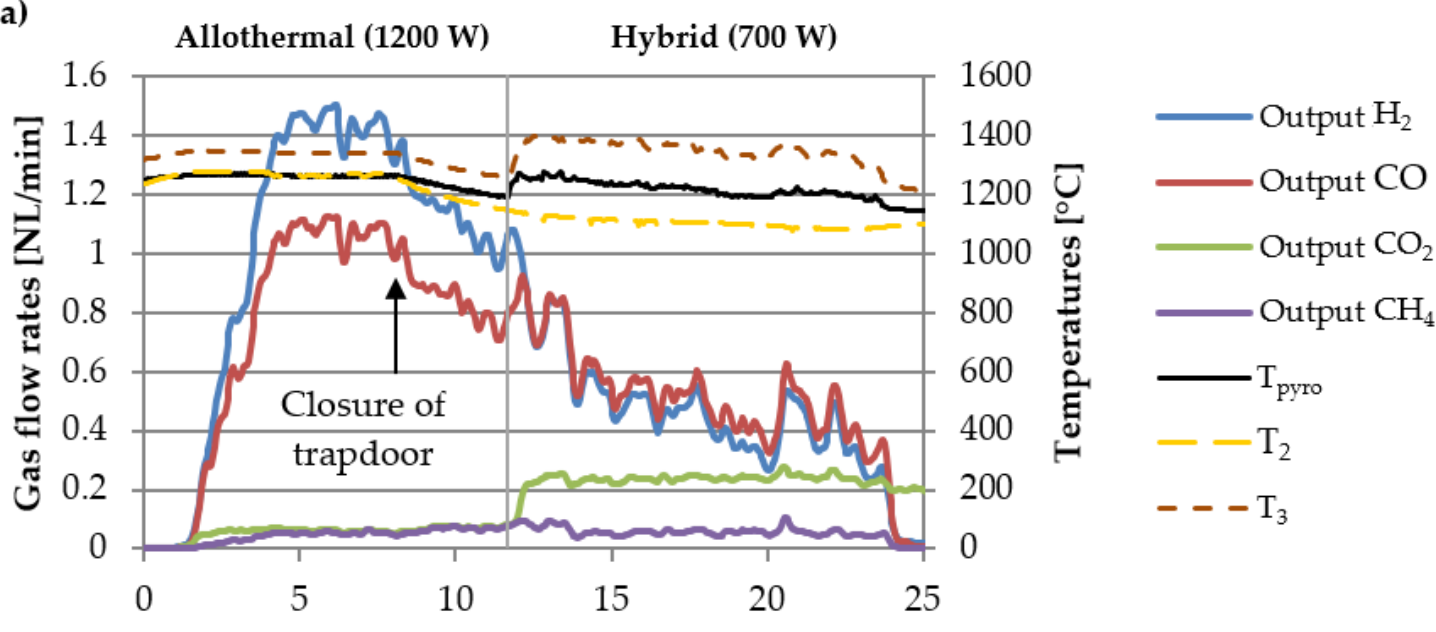

Time $[\min ]$ 
(b)

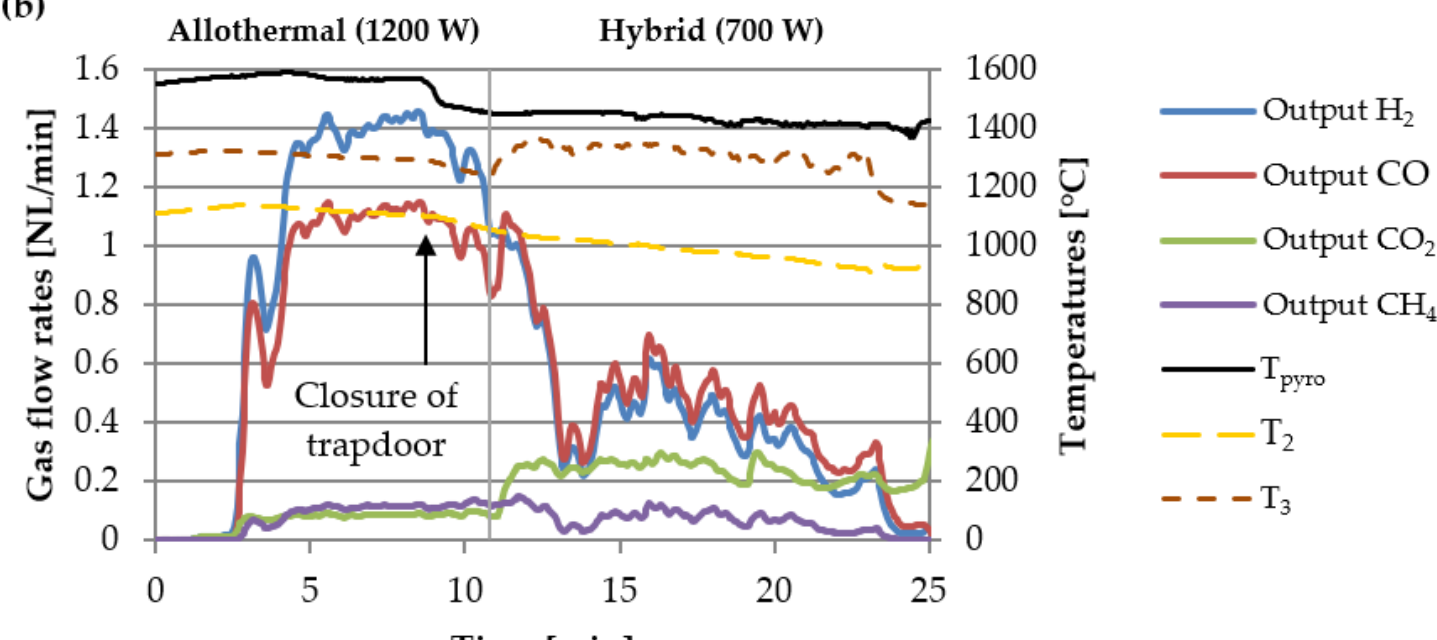

Figure 11. Flow rates of syngas components and temperatures measured during allothermal-hybrid runs featuring a 40\% decrease of the solar power input, in (a) direct (run \#11) and (b) indirect (run \#12) heating modes.

The syngas composition (Figure 12) was evaluated and compared with runs \#5 to \#8. The performance of allothermal gasification was higher than in Figure 9-b thanks to a higher starting temperature (1330 ${ }^{\circ} \mathrm{C}$ ). The $\mathrm{H}_{2}$ yields were increased to 36.0 and $31.6 \mathrm{mmol} / \mathrm{g}_{\text {wood,dry }}$ (direct and indirect heating modes, respectively), the $\mathrm{CO}$ yields to 27.1 and $24.9 \mathrm{mmol} / \mathrm{g}_{\text {wood,dry }}$, and the calculated CGE to $110.2 \%$ and 107.4\%. Meanwhile, the $\mathrm{CO}_{2}$ yields remained as low as $2 \mathrm{mmol} / \mathrm{g}_{\text {wood,dry. Regarding hybrid }}$ gasification, the syngas yields were rather comparable to those of Figure 9-b. The calculated CGE reached respectively 0.89 and 0.92 during hybrid operation.

The drop of solar power input was therefore counterbalanced by a local heating of the cavity center. While the reaction volume was maintained to its initial temperature, the cavity walls cooled down because of the decreased solar power input, which delayed the establishment of a new steady state in the reactor. Even if the syngas quality was affected by hybridization, acceptable performance outputs were obtained, leading to an overall CGE of $100 \%$ in both runs \#11 and \#12. Thus, continuous operation under fluctuating solar irradiation conditions appeared feasible in this hybridized reactor.

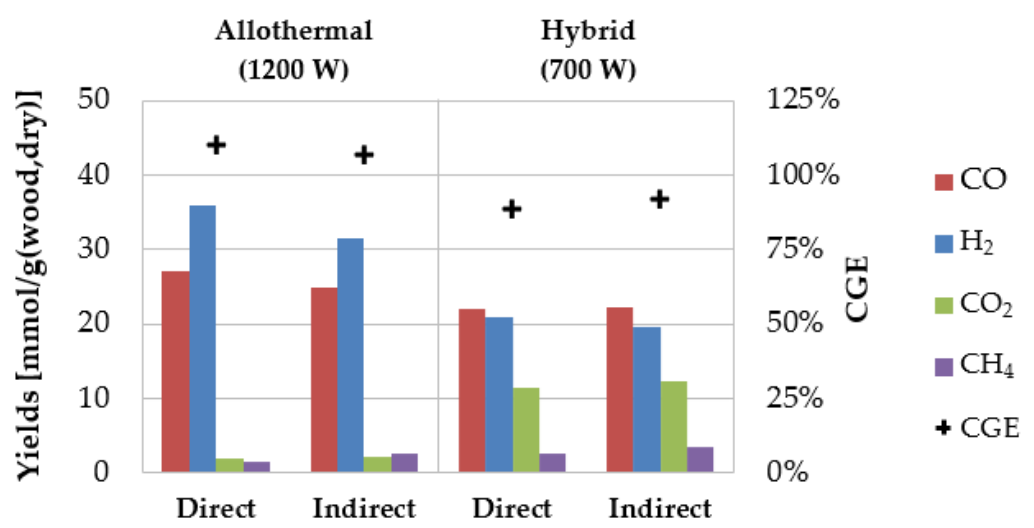

Figure 12. Yields of syngas components and CGE measured during allothermal-hybrid runs featuring a $40 \%$ decrease of the solar power input (runs \#11 and \#12).

\section{CONCLUSION}

The experimental study of a spouted-bed solar gasifier demonstrated that hybridization was effective to heat the gasifier cavity and compensate for drops of solar power input. Oxygen was injected during 
hybrid solar-autothermal operation to compensate solar radiation decrease by combustion, which created a local heating of the cavity volume in the spout region where combustion occurred. The following results and conclusions were achieved:

- Clear relationships were found between the inlet $\mathrm{O}_{2}: \mathrm{C}$ ratio, and the $\mathrm{CO}_{2}$ mole fraction and CGE. Experimental values differed from those predicted at TE, because of kinetic limitation.

- The addition of steam allowed to gasify the feedstock while rising the syngas $\mathrm{H}_{2}: \mathrm{CO}$ ratio. Mixed injection of $\mathrm{H}_{2} \mathrm{O}$ and $\mathrm{O}_{2}$ would thus enable to heat the reactor while controlling the syngas composition, according to thermodynamic equilibrium. This was demonstrated during hybrid runs. The impact of hybridization on syngas production yields was quantified in both direct and indirect heating modes, at nominal temperatures of $1200{ }^{\circ} \mathrm{C}$ and $1300{ }^{\circ} \mathrm{C}$.

- Higher reaction temperatures allowed to reach higher $\mathrm{H}_{2}$ and $\mathrm{CO}$ yields and lower $\mathrm{CO}_{2}$ yields, thanks to improved reaction kinetics.

- Direct heating was more beneficial than indirect heating, as it enhanced the $\mathrm{H}_{2}$ and $\mathrm{CO}$ yields thanks to better heating of the particles. The stability of syngas production was also improved.

- Hybridization, performed after a $40 \%$ drop of the solar power input, was suitable to maintain the cavity temperature at around $1350{ }^{\circ} \mathrm{C}$. An overall CGE of $100 \%$ was found over the entire runs, featuring 10 minutes of allothermal gasification followed by 10 minutes of hybrid gasification.

This study showed the possibility to dynamically control a solar-driven wood gasifier and also provided valuable information about thermal and chemical transient behaviors during change in operating mode between allothermal (solar) and hybrid gasification. It paves the way toward control strategies implementation, by giving orders of magnitude of hybrid operation performance outputs. In further studies, longer hybrid series will be performed with optimized mixtures of oxidants, to better control the performance outputs of hybrid gasification. A dynamic simulation tool will then be developed for controlling the gasification process stability during continuous hybrid operation despite solar resource variability, via the implementation of an accurate hybrid control strategy.

\section{DECLARATION OF COMPETING INTEREST}

The authors declare that they have no known competing financial interests or personal relationships that could have appeared to influence the work reported in this paper.

\section{ACKNOWLEDGEMENTS}

This work received partial funding from the European Union's Horizon 2020 research and innovation program under grant agreement No 823802 (SFERA-III project), along with financial support from CEA (French Alternative Energy and Atomic Energy Commission) and Occitanie Region for the PhD grant of A. Curcio.

\section{REFERENCES}

[1] D.W. Gregg, R.W. Taylor, J.H. Campbell, Solar Gasification of Coal, Activated Carbon, Coke and Coal and Biomass Mixtures, Solar Energy. 25 (1980) 353-364. https://doi.org/10.1016/0038-092X(80)90347-3.

[2] H. Boujjat, S. Rodat, S. Abanades, Techno-Economic Assessment of Solar-Driven Steam Gasification of Biomass for Large-Scale Hydrogen Production, Processes. 9 (2021) 462. https://doi.org/10.3390/pr9030462.

[3] S. Abanades, S. Rodat, H. Boujjat, Solar Thermochemical Green Fuels Production: A Review of Biomass Pyro-Gasification, Solar Reactor Concepts and Modelling Methods, Energies. 14 (2021) 1494. https://doi.org/10.3390/en14051494. 
[4] M. Puig-Arnavat, E.A. Tora, J.C. Bruno, A. Coronas, State of the art on reactor designs for solar gasification of carbonaceous feedstock, Solar Energy. 97 (2013) 67-84. https://doi.org/10.1016/j.solener.2013.08.001.

[5] S. Chuayboon, S. Abanades, An overview of solar decarbonization processes, reacting oxide materials, and thermochemical reactors for hydrogen and syngas production, International $\begin{array}{lllll}\text { Journal of Hydrogen } & \text { Energy. } & 45 & \text { (2020) 25783-25810. }\end{array}$ https://doi.org/10.1016/j.ijhydene.2020.04.098.

[6] R.W. Taylor, R. Berjoan, J.P. Coutures, Solar gasification of carbonaceous materials, Solar Energy. 30 (1983) 513-525. https://doi.org/10.1016/0038-092X(83)90063-4.

[7] N. Piatkowski, A. Steinfeld, Solar-Driven Coal Gasification in a Thermally Irradiated PackedBed Reactor, Energy Fuels. 22 (2008) 2043-2052. https://doi.org/10.1021/ef800027c.

[8] M. Flechsenhar, C. Sasse, D.S.-D. Luft, Solar Gasification of Biomass Using Oil Shale and Coal as Candidate Materials, Energy. 20 (1995) 803-810.

[9] Q. Bellouard, S. Abanades, S. Rodat, N. Dupassieux, Solar thermochemical gasification of wood biomass for syngas production in a high-temperature continuously-fed tubular reactor, International Journal of Hydrogen Energy. 42 (2017) 13486-13497. https://doi.org/10.1016/j.ijhydene.2016.08.196.

[10] N. Gokon, T. Izawa, T. Abe, T. Kodama, Steam gasification of coal cokes in an internally circulating fluidized bed of thermal storage material for solar thermochemical processes, International Journal of Hydrogen Energy. 39 (2014) 11082-11093. https://doi.org/10.1016/j.ijhydene.2014.05.124.

[11] A. Zgraggen, P. Haueter, D. Trommer, M. Romero, J. Dejesus, A. Steinfeld, Hydrogen production by steam-gasification of petroleum coke using concentrated solar power-II Reactor design, testing, and modeling, International Journal of Hydrogen Energy. 31 (2006) 797-811. https://doi.org/10.1016/j.ijhydene.2005.06.011.

[12] J. Matsunami, S. Yoshida, Y. Oku, O. Yokota, Y. Tamaura, M. Kitamura, Coal Gasification by CO2 Gas Bubbling in Molten Salt for Solar / Fossil Energy Hybridization, Solar Energy. 68 (2000) 257-261. https://doi.org/10.1016/S0038-092X(99)00074-2.

[13] A.P. Bruckner, Continuous duty solar coal gasification system using molten slag and directcontact heat exchange, Solar Energy. 34 (1985) 239-247. https://doi.org/10.1016/0038092X(85)90061-1.

[14] M. Milanese, G. Colangelo, F. Iacobazzi, A. de Risi, Modeling of double-loop fluidized bed solar reactor for efficient thermochemical fuel production, Solar Energy Materials and Solar Cells. 160 (2017) 174-181. https://doi.org/10.1016/j.solmat.2016.10.028.

[15] M. Suárez-Almeida, A. Gómez-Barea, A.F. Ghoniem, C. Pfeifer, Solar gasification of biomass in a dual fluidized bed, Chemical Engineering Journal. 406 (2021) 126665. https://doi.org/10.1016/j.cej.2020.126665.

[16] A. Gómez-Barea, M. Suárez-Almeida, A. Ghoniem, Analysis of fluidized bed gasification of biomass assisted by solar-heated particles, Biomass Conv. Bioref. 11 (2021) 143-158. https://doi.org/10.1007/s13399-020-00865-0.

[17] P. Guo, P.J. van Eyk, W.L. Saw, P.J. Ashman, G.J. Nathan, E.B. Stechel, Performance Assessment of Fischer-Tropsch Liquid Fuels Production by Solar Hybridized Dual Fluidized Bed Gasification of Lignite, Energy Fuels. $29 \quad$ (2015) 2738-2751. https://doi.org/10.1021/acs.energyfuels.5b00007.

[18] F. Müller, P. Poživil, P.J. van Eyk, A. Villarrazo, P. Haueter, C. Wieckert, G.J. Nathan, A. Steinfeld, A pressurized high-flux solar reactor for the efficient thermochemical gasification of carbonaceous feedstock, Fuel. 193 (2017) 432-443. https://doi.org/10.1016/j.fuel.2016.12.036.

[19] S. Dai, Z. Chang, C. Chang, J.S. Akhatov, X. Li, Numerical study on the directly-irradiated vortex reactor for solar CO2 coal gasification, Solar Energy. 188 (2019) 573-585. https://doi.org/10.1016/j.solener.2019.06.035.

[20] Q. Bellouard, S. Abanades, S. Rodat, Biomass Gasification in an Innovative Spouted-Bed Solar Reactor: Experimental Proof of Concept and Parametric Study, Energy Fuels. 31 (2017) 1093310945. https://doi.org/10.1021/acs.energyfuels.7b01839.

[21] Q. Bellouard, S. Rodat, S. Abanades, S. Ravel, P.-É. Frayssines, Design, simulation and experimental study of a directly-irradiated solar chemical reactor for hydrogen and syngas 
production from continuous solar-driven wood biomass gasification, International Journal of Hydrogen Energy. 44 (2019) 19193-19205. https://doi.org/10.1016/j.ijhydene.2018.04.147.

[22] S. Chuayboon, S. Abanades, S. Rodat, Experimental analysis of continuous steam gasification of wood biomass for syngas production in a high-temperature particle-fed solar reactor, Chemical Engineering and Processing - Process Intensification. 125 (2018) 253-265. https://doi.org/10.1016/j.cep.2018.02.004.

[23] J. Matsunami, S. Yoshida, Y. Oku, O. Yokota, Y. Tamaura, M. Kitamura, Coal Gasification by CO2 Gas Bubbling in Molten Salt for Solar / Fossil Energy Hybridization, Solar Energy. 68 (2000) 257-261. https://doi.org/10.1016/S0038-092X(99)00074-2.

[24] B.J. Hathaway, J.H. Davidson, Demonstration of a prototype molten salt solar gasification reactor, Solar Energy. 142 (2017) 224-230. https://doi.org/10.1016/j.solener.2016.12.032.

[25] H. Boujjat, S. Rodat, S. Abanades, Solar-hybrid Thermochemical Gasification of Wood Particles and Solid Recovered Fuel in a Continuously-Fed Prototype Reactor, Energies. 13 (2020) 5217. https://doi.org/10.3390/en13195217.

[26] H. Boujjat, S. Rodat, S. Chuayboon, S. Abanades, Experimental and numerical study of a directly irradiated hybrid solar/combustion spouted bed reactor for continuous steam gasification of biomass, Energy. 189 (2019) 116118. https://doi.org/10.1016/j.energy.2019.116118.

[27] M.A. Mayers, The Rate of Oxidation of Graphite by Steam, J. Am. Chem. Soc. 56 (1934) 1879 1881. https://doi.org/10.1021/ja01324a015.

[28] J.M. Thomas, Reactivity of carbon: Some current problems and trends, Carbon. 8 (1970) $413-$ 421. https://doi.org/10.1016/0008-6223(70)90001-1.

[29] C. Diblasi, Modeling chemical and physical processes of wood and biomass pyrolysis, Progress in Energy and Combustion Science. 34 (2008) 47-90. https://doi.org/10.1016/j.pecs.2006.12.001.

[30] J. Cai, W. Wu, R. Liu, An overview of distributed activation energy model and its application in the pyrolysis of lignocellulosic biomass, Renewable and Sustainable Energy Reviews. 36 (2014) 236-246. https://doi.org/10.1016/j.rser.2014.04.052.

[31] S. Vakalis, F. Patuzzi, M. Baratieri, Thermodynamic modeling of small scale biomass gasifiers: Development and assessment of the "Multi-Box" approach, Bioresource Technology. 206 (2016) 173-179. https://doi.org/10.1016/j.biortech.2016.01.060.

[32] M. Cortazar, J. Alvarez, G. Lopez, M. Amutio, L. Santamaria, J. Bilbao, M. Olazar, Role of temperature on gasification performance and tar composition in a fountain enhanced conical spouted bed reactor, Energy Conversion and Management. 171 (2018) 1589-1597. https://doi.org/10.1016/j.enconman.2018.06.071.

[33] S. Chuayboon, S. Abanades, S. Rodat, Comprehensive performance assessment of a continuous solar-driven biomass gasifier, Fuel Processing Technology. 182 (2018) 1-14. https://doi.org/10.1016/j.fuproc.2018.10.016.

[34] S. Chuayboon, S. Abanades, S. Rodat, Insights into the influence of biomass feedstock type, particle size and feeding rate on thermochemical performances of a continuous solar gasification reactor, Renewable Energy. 130 (2019) 360-370. https://doi.org/10.1016/j.renene.2018.06.065.

[35] H. Boujjat, S. Rodat, S. Chuayboon, S. Abanades, Experimental and CFD investigation of inert bed materials effects in a high-temperature conical cavity-type reactor for continuous solardriven steam gasification of biomass, Chemical Engineering Science. 228 (2020) 115970. https://doi.org/10.1016/j.ces.2020.115970.

[36] H.C. Yoon, T. Cooper, A. Steinfeld, Non-catalytic autothermal gasification of woody biomass, International Journal of Hydrogen Energy. 36 (2011) 7852-7860. https://doi.org/10.1016/j.ijhydene.2011.01.138.

[37] X. Li, Y. Shen, X. Kan, T.K. Hardiman, Y. Dai, C.-H. Wang, Thermodynamic assessment of a solar/autothermal hybrid gasification CCHP system with an indirectly radiative reactor, Energy. 142 (2018) 201-214. https://doi.org/10.1016/j.energy.2017.09.149.

[38] J. Petrasch, P. Osch, A. Steinfeld, Dynamics and control of solar thermochemical reactors, Chemical Engineering Journal. 145 (2009) 362-370. https://doi.org/10.1016/j.cej.2008.07.051.

[39] E. Saade, D.E. Clough, A.W. Weimer, Model predictive control of a solar-thermal reactor, Solar Energy. 102 (2014) 31-44. https://doi.org/10.1016/j.solener.2013.12.029. 
[40] A. Muroyama, T. Shinn, R. Fales, P.G. Loutzenhiser, Modeling of a Dynamically-Controlled Hybrid Solar/Autothermal Steam Gasification Reactor, Energy Fuels. 28 (2014) 6520-6530. https://doi.org/10.1021/ef501535r.

[41] H. Boujjat, G.M. Yuki Junior, S. Rodat, S. Abanades, Dynamic simulation and control of solar biomass gasification for hydrogen-rich syngas production during allothermal and hybrid solar/autothermal operation, International Journal of Hydrogen Energy. 45 (2020) 25827-25837. https://doi.org/10.1016/j.ijhydene.2020.01.072.

[42] A.P. Muroyama, I. Guscetti, G.L. Schieber, S. Haussener, P.G. Loutzenhiser, Design and demonstration of a prototype $1.5 \mathrm{~kW}$ th hybrid solar/autothermal steam gasifier, Fuel. 211 (2018) 331-340. https://doi.org/10.1016/j.fuel.2017.09.059.

[43] B.J. Hathaway, J.H. Davidson, Autothermal hybridization and controlled production of hydrogen-rich syngas in a molten salt solar gasifier, International Journal of Hydrogen Energy. (2021) S0360319921005322. https://doi.org/10.1016/j.ijhydene.2021.02.048.

[44] H. Boujjat, S. Rodat, S. Abanades, C. Perret, Simulation of biomass gasification in a novel hightemperature directly irradiated hybrid solar/combustion reactor, in: Casablanca, Morocco, 2019: p. 180005. https://doi.org/10.1063/1.5117685.

[45] D.G. Goodwin, H.K. Moffat, R.L. Speth, Cantera: an Object-oriented Software Toolkit for Chemical Kinetics, Thermodynamics, and Transport Processes, 2021.

[46] H. Boujjat, S. Rodat, S. Chuayboon, S. Abanades, Numerical simulation of reactive gas-particle flow in a solar jet spouted bed reactor for continuous biomass gasification, International Journal $\begin{array}{llllll}\text { of Heat and Mass Transfer. } 144 & \text { (2019) } & 118572 .\end{array}$ https://doi.org/10.1016/j.ijheatmasstransfer.2019.118572. 